\title{
Biomimetic flow fields for Proton Exchange Membrane Fuel Cells: a review of Design Trends
}

\author{
A. Iranzo ${ }^{a^{*}}$, C. H. Arredondo ${ }^{b}$, A. M. Kannan ${ }^{c}$, F. Rosa ${ }^{a}$

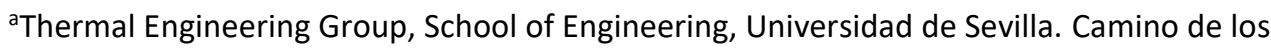 \\ Descubrimientos, s/n, 41092, Sevilla, Spain. \\ bÁrea Académica de Ingeniería en Energía, Universidad Politécnica de Francisco I Madero, Domicilio \\ conocido s/n, Tepatepec, Francisco I. Madero, C.P. 42660 Hidalgo, México. \\ 'The Polytechnic School, Ira A. Fulton Schools of Engineering, Arizona State University, Mesa, AZ 85212, \\ USA \\ (*) corresponding author: email: airanzo@us.es; Tel. (+34) 954 487471; Fax (+34) 954463153
}

\begin{abstract}
Bipolar Plate design is one of the most active research fields in Polymer Electrolyte Membrane Fuel Cells (PEMFCs) development. Bipolar Plates are key components for ensuring an appropriate water management within the cell, preventing flooding and enhancing the cell operation at high current densities. This work presents a literature review covering bipolar plate designs based on nature or biological structures such as fractals, leaves or lungs. Biological inspiration comes from the fact that fluid distribution systems found in plants and animals such as leaves, blood vessels, or lungs perform their functions (mostly the same functions that are required for bipolar plates) with a remarkable efficiency, after millions of years of natural evolution. Such biomimetic designs have been explored to date with success, but it is generally acknowledged that biomimetic designs have not yet achieved their full potential. Many biomimetic designs have been derived using computer simulation tools, in particular Computational Fluid Dynamics (CFD) so that the use of CFD is included in the review. A detailed review including performance benchmarking, time line evolution, challenges and proposals, as well as manufacturing issues is discussed.
\end{abstract}

Keywords: biomimetics; biologically-inspired design; nature-inspired design; bionic; fuel cell; bipolar plate

\section{Introduction}

Biomimetics is the discipline that analyse systems, elements and patterns of nature in order to derive technological designs of engineering interest. Biomimetics tries to make use of the millions of years of living organisms evolution via natural selection, observing their remarkably well-adapted structures and materials. Since one of the functions of Fuel Cell Bipolar Plates (BPPs) is to distribute reactants and evacuate waste products, exactly as some structures of many living organisms do, there has been an increasing trend aiming at recreating natureinspired Bipolar Plates with higher performance. Such efforts focused on Bipolar Plates started short after year 2000. The review article published by Arvay et al. [1] in 2013 provided the first good analysis and overview of the research work done on this field. Since year 2013 however, the research work on nature-inspired (biomimetic) flow fields have continued significantly, including recent articles using for the first time advanced visualization techniques such as Neutron Imaging for the investigation of water management in biomimetic designs. As a result 
of the growth experienced in this particular research topic during the last years, the present review is including a further updated discussion on the field with respect to the previous work published in 2013 by Arvay et al. [1]. In addition, apart from the analysis of the different design types, the review is including a time evolution analysis of the design trends together with a critical analysis of the quantitative performance achieved by each design, so that more rational decisions can be made for future research directions. The present review intends to provide a new analysis and insight into the latest advances and contributions to the state-of-the-art.

The review is organised as follows: first, a brief description and discussion on Bipolar Plates is provided. This will be covered shortly as the focus of the review is the biomimetic design. As most of the research work for deriving biomimetic designs is based on Computational Fluid Dynamics modelling, a section covering this is provided. In Section 4 the review on the natureinspired Bipolar Plates will be introduced and discussed, sorted based on design types such as lung or leaves. Fractal-based designs are also included in the review, as well as the most relevant works on porous foams as these can be considered as marine sponges. An effort to condense the major findings and results is presented in the form of tables featuring the most relevant information for researchers and designers. For this, a quantitative analysis of relevant performance parameters achieved by each design reported in the literature has been carried out in order to enable the assessment of the benefits of the novel biomimetic designs. The parameter used for this is the gain in performance with respect to a conventional design, where this information has been extracted from the polarization curves reported in the different works. The performance gain is calculated as the current density improvement for the biomimetic bipolar plate with respect to the conventional design, at $0.6 \mathrm{~V}$ (considered to be a nominal point) and at $0.4 \mathrm{~V}$ (more representative of operating conditions at high current densities where the influence of the Bipolar Plate design is much more pronounced). Finally, the current status on the discipline is analysed and major challenges and proposals for evaluating designs are presented.

\section{Bipolar plates}

Bipolar plates in a fuel cell are placed at both sides of the Membrane Electrode Assembly (MEA) and connect each single cell to each other in a stack.

\subsection{Functions and requirements}

The bipolar plates carry out several functions in a fuel cell stack, and therefore demand different mechanical, thermal, and chemical properties. These required functions are [2-4]:

1. BPPs electrically connect the cells in series and transport the generated current through the land towards the current collectors.

2. BPPs separate the gases in the adjacent anode and cathode sides of the cell.

3. BPPs provide the structural and mechanical support for the stack, yet they must be lightweight in particular for transport applications.

4. BPPs distribute the reactants gases towards the Gas Diffusion Layer (GDL) and electrodes, and also evacuate the unreacted gases and the products in gas and liquid states. BPPs have a major influence on the water management of the cell and therefore on the final performance and durability [5-7].

5. BPPS must also be thermally conductive in order to contribute to the heat rejection., and be chemically inert. 
The U.S. Department of Energy (DOE) summarises the requirements for BPPs as indicated in Table 1 [8].

Table 1. Bipolar plate design criteria [8].

Technical Targets: Bipolar Plates for Transportation Applications

\begin{tabular}{|c|c|c|c|}
\hline Characteristic & Units & 2015 Status & 2020 Targets \\
\hline Cost & $\$ / K W$ net & 7 & 3 \\
\hline Plate weight & $\mathrm{Kg} / \mathrm{KW}_{\text {net }}$ & $<0.4$ & 0.4 \\
\hline $\begin{array}{l}\text { Plate } \mathrm{H}_{2} \text { permeation } \\
\text { coefficient }\end{array}$ & $\begin{array}{l}\text { STD } \mathrm{cm}^{3} /\left(\mathrm{sec} \mathrm{cm}^{2} \mathrm{~Pa}\right) @ \\
80^{\circ} \mathrm{C}, 3 \mathrm{~atm} 100 \% \mathrm{RH}\end{array}$ & 0 & $<1.3 \times 10^{-14}$ \\
\hline Corrosion, anode & $\mu \mathrm{A} / \mathrm{cm}^{2}$ & No active peak & $\begin{array}{l}<1 \text { and no active } \\
\text { peak }\end{array}$ \\
\hline Corrosion, cathode & $\mu \mathrm{A} / \mathrm{cm}^{2}$ & $<0.1$ & $<1$ \\
\hline Electrical conductivity & $\mathrm{S} / \mathrm{cm}$ & $>100$ & $>100$ \\
\hline $\begin{array}{l}\text { Areal specific } \\
\text { resistance (ASR) }\end{array}$ & $\mathrm{ohm} \mathrm{cm} \mathrm{cm}^{2}$ & 0.006 & $<0.01$ \\
\hline Flexural strength & $\mathrm{MPa}$ & $>34$ (carbon plate) & $>25$ \\
\hline Forming elongation & $\%$ & $20-40$ & 40 \\
\hline
\end{tabular}

It can be observed that some of the targets for 2020 were already achieved in state-of-the-art bipolar plates in 2015 , such as plate weight $\left(0.4 \mathrm{~kg} / \mathrm{kW}_{\text {net }}\right)$, areal specific resistance or electrical conductivity $(>100 \mathrm{~S} / \mathrm{cm})$. However, some of the parameters still require significant improvement. The cost is one of the most significant (and challenging) characteristic to be improved for 2020, from $7 \$ / \mathrm{kW}_{\text {net }}$ in the 2015 status down to a requirement of $3 \$ / \mathrm{kW}_{\text {net }}$ in 2020 (both in terms of costs projected to high volume production of 500,000 units of $80 \mathrm{~kW}$ systems per year).

\subsection{Flow field layout design}

The flow field design refers to the geometry of the channels featured by the Bipolar Plate. It must be considered that channels can be machined (typically in graphite plates) or conformed by different techniques (die stamping, forming, and others, typically in metal-based BPPs) [4, 911]. The most widespread and conventional channel configurations for PEMFCs are depicted in Figure 1. 

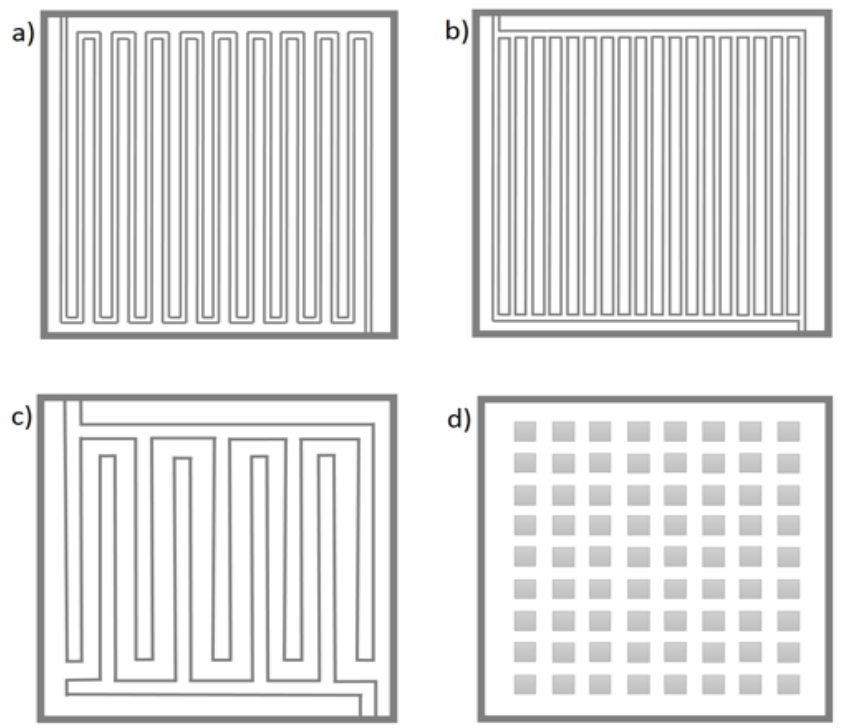

Figure 1. Conventional flow field designs: a) Single Serpentine, b) Parallel, c) Interdigitated, d) pin-type or column.

Not only a failure in the flow distribution among the different channels may severely influence the cell performance, but also dramatic improvements in the cell current density generation and durability can be achieved by means of an improved flow field design.

Intensive research efforts are carried out in order to investigate the most performing flow field layouts [2,12-18], configurations (co-flow, counter-flow) [2, 19-22] and orientations (vertical or horizontal channels, horizontal facing upwards or downwards) [15, 23-27].

\subsection{Channel cross-section geometries}

Once a flow field main layout and configuration is achieved, further optimization work can be done when it comes to designing the final channel dimensions (width and depth), and also the cross-section geometry [12, 28-30]. The review published by Manso et al. [31] presents conclusions related to the influence of the different flow channel geometric parameters on the overall performance of a PEMFC. Guidelines regarding flow fields, flow direction, channel length and number of channels, use of baffles, cross section shape, channel and rib width, channel depth, and height to width ratio are provided. It must be considered that the use of full or partial channel blockages is also affecting the gas transport, water removal capability, and thus the overall cell performance, as stated in the work by Heidary et al. [32].

\section{Flow field Designs: Computational Fluid Dynamics modelling}

Computational Fluid Dynamics (CFD) has been established as a fundamental tool for the research and design of PEM Fuel Cells. Modelling and simulation constitutes a major working field in PEMFCs research, with several modelling approaches being used and developed [40-43]. Initially, only a single channel was typically resolved, but currently the main application of CFD for PEM Fuel Cells is the single cell modelling, with cell sizes ranging from micro-fuel cells [44, 45] up to massive parallel computations of large fuel cells [46-48]. However other CFD 
simulations are available in the literature, such as small stack simulations $[49,50]$ stack gas manifold simulations [51], and others.

All CFD models reported in the literature include assumptions and hypotheses, where the most common are steady state operating conditions, ideal gas, laminar flow, isotropic and homogeneous GDL, CL and membrane, and no effect of gravity. Obviously some of them such as isotropic materials are highly questionable [52]. In recent years, other assumptions such as single-phase flow modelling (without liquid water) are less present in CFD modelling, as it is obvious that liquid water has a fundamental role in the performance of PEM Fuel Cells. Some of the conclusions that can be drawn from a literature review on PEMFC CFD modelling are the following:

-Multiphase flow is one of the more difficult physical phenomena to correctly model $[40,53]$. The effects of water transport and distribution are also of major importance for the cell operation and performance, and therefore the lack of accurate models, valid for all regimes of flow and cell operation, is a concern in the modelling activities.

-Model validation is absolutely fundamental for the development and confident use of models. It is known that the validation using only the polarization IV curves is typically not sufficient as stated by Wang [40], as the polarization curve is an integral output of the cell and the coupling of the different phenomena occurring within the cell can provide the same or similar polarization curves under certain circumstances, without being each of the phenomena correctly modelled. A validation procedure against local quantities is therefore necessary [40]. These quantities can be species distributions, current density distributions, or liquid water distributions measured by optical means in transparent cells, or advanced visualization techniques such as X-ray radiography or neutron imaging $[54,55]$ as reported by Weber and Hickner [56], Wand and Chen [57], Iranzo et al. [58] (reproduced in Figure 2) or Quan and Lai [59].

-Additional issues such as an appropriate convergence methodology and the lack of reliable and robust input data must be also considered to ensure that accurate results are obtained, as stated by Arvay et al. [60] and Bednarek and Tsotridis [61].

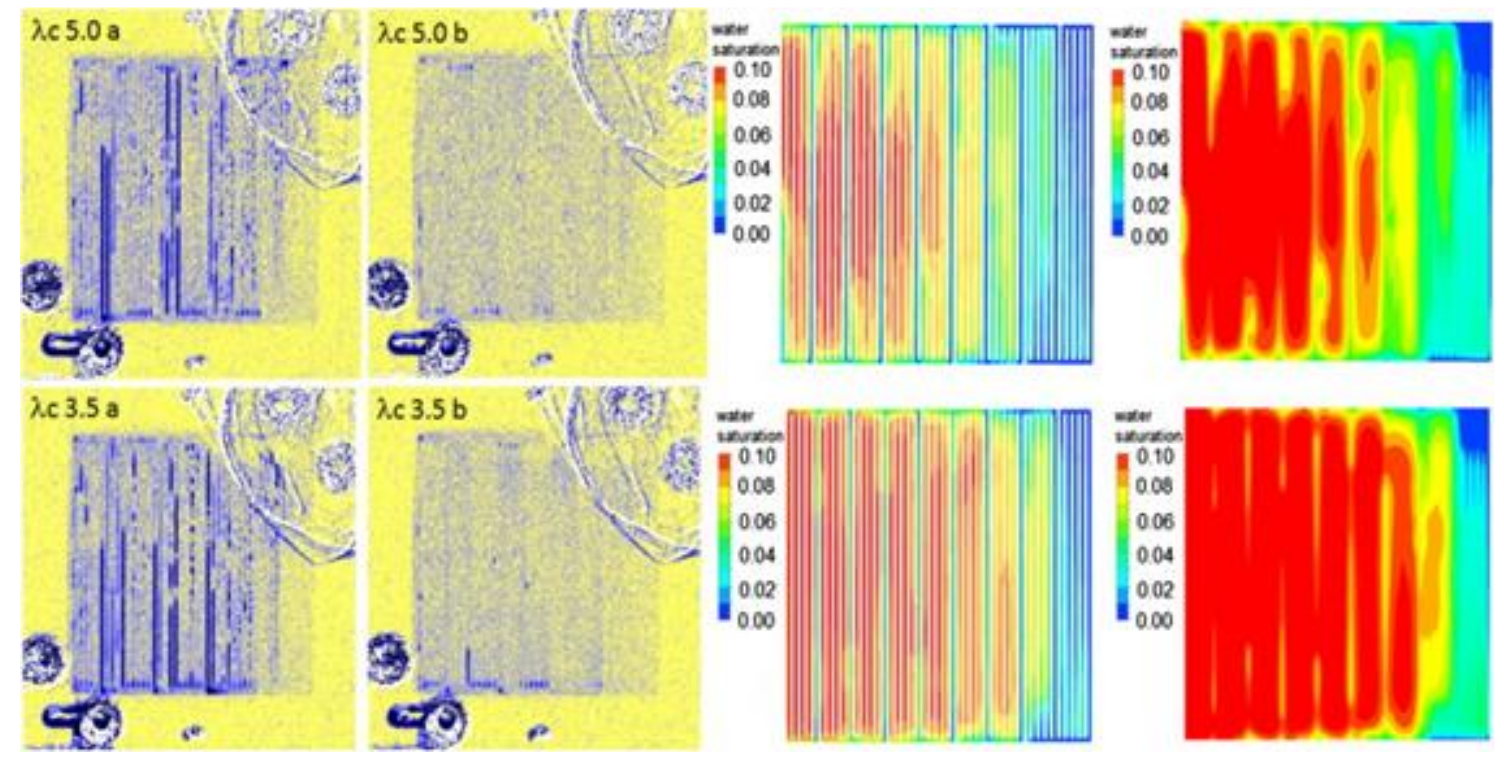

Figure 2. Neutron radiographs of liquid water distributions (left) obtained for the validation of CFD modelling results (right) [58 - Reproduced with permission from Elsevier]. 


\subsection{Cell geometry and meshing}

Fuel Cells are presenting particular challenges for mesh generation, mainly due to the very different length scales of the cell components (a few microns for membrane and catalyst thickness, up to bipolar plates with sizes of a few decimetres in industrial designs). This makes necessary to use hexahedral meshing, with a solver able to handle cells with high aspect ratios (double precision solvers are sometimes required). Bipolar plate geometries have become more sophisticated along the time-evolution of Fuel Cell design. This is also involving large efforts in accurately generating a mesh with high quality where most of the times, and in particular for industrial cells, very thin metallic plates with typically of $0.1 \mathrm{~mm}$ thickness are being used with integrated cooling channels.

Regarding the cell size, it is well known within the CFD community that Quality\&Trust in CFD modelling and simulation must be ensured. Best Practice Guidelines has been established for CFD applications, although these are still in their infancy for the particular case of PEMFC. A fundamental step for this is to carry out a mesh independence analysis. This is required in order to ensure that the results provided by the model are not depending on the mesh being used (i.e. further mesh refinements do not increase the accuracy of the model). Although such activity is not yet regularly reported in the literature, it is becoming a standard to include a mesh independence study within the initial steps of the CFD analysis, which is obviously necessary in order to ensure the quality and accuracy of the results. As an example, among 60 references found in the literature for CFD PEMFC modelling between 2011 and 2018, only 24 claimed to have carried out a mesh independence analysis, where less than 10 [62-71] actually presented enough data regarding the analysis details (number of elements used for each mesh used, results obtained, etc.). It is worth to mention the recent work of Choopanya and Zhang [72], where a detailed analysis of the influence of the mesh resolution in each direction (throughplane and in-plane) is assessed. They demonstrated that the correct resolution of the throughplane direction is critical for the accuracy of the CFD model results. When observing the data within the references identified with detailed mesh independence analysis [62-71], it can be concluded that the amount of elements required per $\mathrm{cm}^{2}$ of cell active area is approximately 100,000 elements. This must however be considered as a rough estimation and not an absolute guide for mesh generation, as the number of elements for achieving mesh independent results will be highly influenced by the particularities of the cell geometry.

There are some particularities regarding geometry/mesh generation which depend on the software being used. Some software considers the catalyst layer as an infinitely thin layer, and thus geometry and mesh is 2D. This is the case of Star-CD [29, 47, 73]. In other cases such as in ANSYS-FLUENT, the catalyst layer is considered as a 3D layer with a given thickness $[68,74,75]$, and therefore the $3 \mathrm{D}$ geometry must be resolved in the mesh.

\subsection{Material properties (membrane, electrodes, GDL, bipolar plates)}

Material properties must be defined for each cell component as well as for the gases involved. The properties that must be defined are summarized in Table 2. In addition to physical properties, also model parameters must be defined (for example for the Butler-Volmer equation for the electrochemical reactions). Typical model parameters found in the literature are presented in Table 3. Some of the model parameters are difficult to determine either 
experimentally or from literature data, and thus are frequently used to fit the experimental data and calibrate the model results for validation purposes. It must be considered however that ideally no more than one model parameter should be used for model fitting [68] in order to ensure the model validation and usefulness for a wider usage (performance prediction at different operating conditions or with other materials).

Table 2. Material properties required for PEM fuel cell modelling (membrane, electrodes, GDL, bipolar plates)

\begin{tabular}{lc} 
Physical Property & Units \\
\hline Material electric conductivity & $1 / \Omega \mathrm{m}$ \\
Material thermal conductivity & $\mathrm{W} / \mathrm{m} \mathrm{K}$ \\
Material specific heat $\left(^{*}\right)$ & $\mathrm{J} / \mathrm{Kg} \mathrm{K}$ \\
Material density $\left(^{*}\right)$ & $\mathrm{Kg} / \mathrm{m}^{3}$ \\
Catalyst surface-to-volume ratio & $1 / \mathrm{m}$ \\
GDL and Catalyst layer porosity & - \\
GDL and Catalyst layer permeability & $\mathrm{m}^{2}$ \\
GDL - Bipolar Plate electric contact resistivity & $\Omega \mathrm{m}^{2}$ \\
Membrane equivalent weight & $\mathrm{Kg} / \mathrm{Kmol}$ \\
Membrane protonic conductivity & $1 / \Omega \mathrm{m}$ \\
$\mathrm{H}_{2}, \mathrm{O}_{2}, \mathrm{H}_{2} \mathrm{O}$ diffusion coefficients & $\mathrm{m}^{2} / \mathrm{s}$
\end{tabular}

$(*)$ : only required for transient simulations

\subsection{Model parameters}

Table 3. Model parameters required for the modelling of PEM fuel cells.

\begin{tabular}{lc} 
Parameter & Units \\
\hline Open Circuit Voltage & $\mathrm{V}$ \\
Reference exchange current density at anode and cathode $\left(^{*}\right)$ & $\mathrm{A} / \mathrm{m}^{3}$ \\
Anode and cathode reference concentration & $\mathrm{Kmol} / \mathrm{m}^{3}$ \\
Anode and cathode concentration exponent & - \\
Anode and cathode charge transfer coefficient & - \\
GDL and Catalyst layer viscous resistance & $1 / \mathrm{m}^{2}$ \\
Pore blockage saturation exponent & - \\
be referenced to $\mathrm{cm}^{2} \mathrm{Pt}$, with units $\mathrm{A} / \mathrm{cm}^{2} \mathrm{Pt}$ &
\end{tabular}

It is important to highlight that results based on CFD modelling should be always reporting the comprehensive list of material properties and model parameters used, for the sake of completeness and reproducibility of the results. Obviously, also the detailed operating conditions must be fully reported (gas and coolant inlet mass flow and temperature, relative humidity, stoichiometry, species mass fractions), external conditions for heat transfer simulations, and anode/cathode voltages and current density depending on galvanostatic or potentiostatic operation.

\section{Flow Field Designs: Nature inspired (biomimetic) design of bipolar plates}


In this section the available literature on biomimetic flow field designs is presented, sorted by design type. It must be considered that there is no standardized term in the literature for the discipline of nature-inspired design of bipolar plates, and terms such as bio-inspired, bionic, biomimetic, can be found in the different publications.

\subsection{Fractal designs}

After a detailed literature survey, it was identified that the first work dealing with fractal structures for bipolar plates was published by Tüber et al [76] in 2004. The authors designed fractal structures with a multiple ramified fluid network for flow-fields in PEMFCs and DMFCs aimed at portable applications. A computer algorithm was developed aimed at achieving a uniform fluid distribution with minimum pressure loss. Experimental prototypes were manufactured and tested, and compared with conventional serpentine and parallel flow-fields. In their work, both PEMFCs and DMFCs fractal flow-fields showed similar performance to parallel designs, although indeed the most stable and highest power output was reached by the serpentine flow-field.

Chang et al [77] also published a work about fractal structures for DMFCs in 2008. They investigated which geometric parameters had more influence on the cell performance. It was demonstrated that the cathode BP had a greater influence on the performance than the anode BP. A similar work also for DMFCs was carried out by Kuan et al [78] in 2009. They presented a continuous type fractal geometry based on the Hilbert curve, where a sketch of the resulting geometry based on the third order Hilbert curve is shown in Figure 3. The experimental testing of the different designs showed that higher performances were obtained with a larger free open ratio and total perimeter length of the open carved designs.

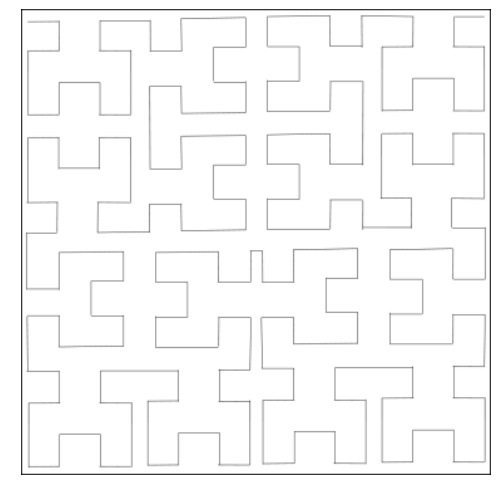

Figure 3. Flow Field design based on fractal geometry from Hilbert curve, by Kuan et al [78].

Kjelstrup et al [79] in 2010 also investigated a fractal structure inspired by the human lung, with the aim to improve energy efficiency and to reduce the total amount of catalyst. They worked with a tree-like gas distributor engraved in the bipolar plates removing the need for a porous transport layers (GDL). As a result, it was expected that the amount of catalyst could be reduced by a factor of $4-8$, while the energy efficiency could be increased by $10-20 \%$ at high current densities. Based on CFD simulations, Ramos-Alvarado et al [80] analysed in 2011 a plate-type constructal flow distributor. Three constructal flow configurations were studied, where each pattern was a fractal expansion of the original design. It was found that the number of branches was the key parameter in the performance, where the constructal flow distributor presented a low pressure drop as well as a good uniformity of flow distribution. 
Cheng et al [81] applied an imitation of biological development of the topology distribution for the design of a fractal tree-like network channel. Different Reynolds numbers and stoichiometric factors were investigated by 3D CFD analysis. Numerical results showed that the fractal tree-like network channel presented a good performance regarding the uniformity of multi-branching flow distribution and pressure drop along channels. The last work identified with fractal structures was published in 2014 by Chang et al [82], who presented the application of Hilbert fractal curves to direct methanol fuel cell (DMFC) current collectors.
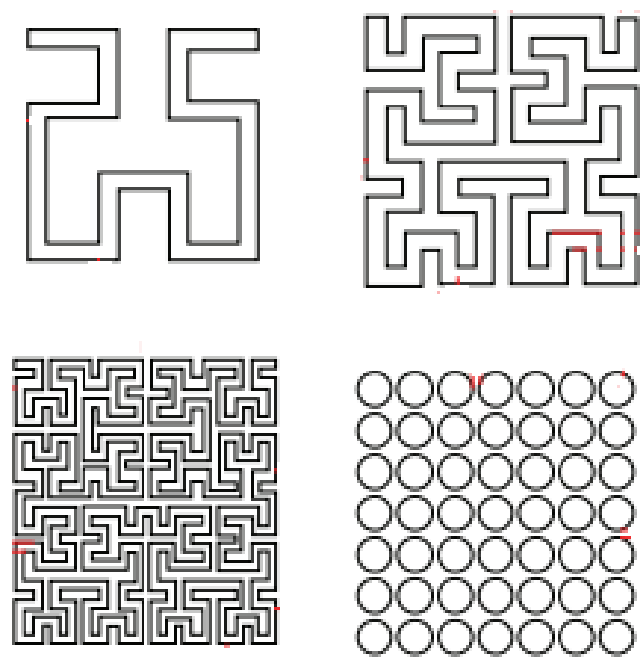

Figure 4. Fractal design based on Hilbert fractal curves, by Chang et al [82].

The current collectors were manufactured following first, second, and third order Hilbert fractal curves (Figure 4), where different free open ratios and opening perimeters were obtained. Experimental work was carried out for the prototypes, also including Electrochemical Impedance Spectroscopy (EIS) experiments. Experimental polarization curves and power curves showed that design with the third order fractal curve was achieving the highest performance. It is worth to mention that this is the only work where EIS Nyquist plots are reported. The results obtained showed that the impedance of the third order fractal design was the lowest.

\subsection{Biologically inspired design}

Regarding designs inspired in biological systems and structures, it is worth introducing the Murray's law, which is being used by many authors to determine the flow channel widths of different generations or branches. Murray's law describes the optimum configuration of diameters found in biological circulatory systems, stating that the cube of the radius of the parent branch should be equal to the sum of the cubes of the radii of the daughter branches. This is expressed as:

$r_{p}^{3}=r_{d 1}^{3}+r_{d 2}^{3}+\cdots+r_{d n}^{3}$

where $r_{p}$ is the radius of the parent channel and $r_{d}$ are the radii of the daughter channels. For the particular case of non-circular cross-section channels, the hydraulic diameter must be used in Eq. (1). Pulmonary and vascular systems of animals and also circulatory systems in some plants are very well represented by Murray's law [83]. As it will be introduced in the next sub- 
section, Murray's law was used mostly for deigns inspired in leaves, but also in others such as pitchforks.

\subsubsection{Leaves}

Leaves are probably one the best examples inspiring how nature can distribute reactants (nutrients) over a 2D surface, and therefore they have been used as inspiration for a wide variety of designs and works.

The first one identified corresponds to the work of Kloess et al [84] in 2009. They presented a flow field design inspired by a leaf (and a second design based on lungs). In total four designs were analysed, namely single serpentine, interdigitated, lung, and leaf flow patterns. Both numerical simulation and experimental testing were conducted, where a lower pressure drop was obtained in the leaf or lung design (26-27 Pa) with respect to existing interdigitated or single serpentine flow patterns (38-41 Pa). Gas transport through the gas diffusion layer was also found be to more uniform for the new flow channel patterns. Experimental tests were carried out for a $25 \mathrm{~cm}^{2}$ fuel cell under different operating conditions. The fuel cell with either leaf or lung design was found to perform better than the convectional flow channel designs under the same operating conditions, with up to $30 \%$ improvements in peak power density. In addition, the effect of cell temperature, relative humidity or cell backpressure was analysed, identifying optimum operating conditions for the leaf and lung design at $65-75^{\circ} \mathrm{C}, 2 \mathrm{~atm}$ backpressure, and $100 \%$ relative humidity.

Currie [85] presented in 2010 a thesis where biomimetics was applied to the redesign of fuel cell flow fields. A number of designs biologically inspired where evaluated by means of CFD modelling, with the objective of achieving a uniform current density distribution across the membrane. A design inspired by Murray's law of branching in plants and animals was further evaluated using a physical model and comparing it to a commercial triple serpentine flow field. Although it was found to present lower pressure drop, the Murray's law inspired flow field was reported to be more prone to flooding.

Guo et al [86] presented a mathematical model for the simulation of flow fields inspired in leaf veins, aiming at achieving minimal pressure drop, lowest energy dissipation, and uniform gas distribution. The Bipolar Plates derived are schematically represented in Figure 5. Finite element modelling (FEM) based simulations and experiments with the biomimetic bipolar plates manufactured by Selective Laser Sintering (SLS) were carried out to verify the performance of the flow field designs. 

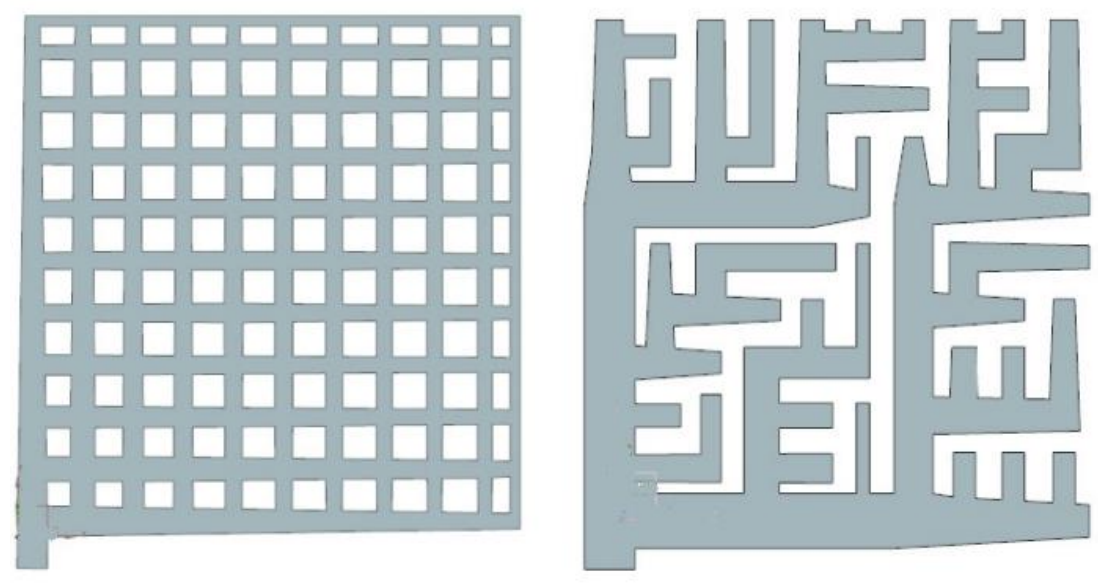

Figure 5. Design based on tree-like structure, by Guo et al. [86]

A two dimensional numerical model was used by Arbabi et al [87] in 2012 to assess the performance of a newly proposed flow field with inspiration from plant leaves. Overall pressure drop and uniform pressure and velocity distributions throughout the flow channels were found to be much more homogeneous in the new channel design, therefore showing a good potential for designs with higher performances.

Tao Chen et al. at the School of Mechanical and Electronic Engineering, Wuhan University of Technology, have carried out several investigations on biomimetic designs based on leafs. In 2012, they presented a research [88] where the bionic similarity theory was used to design bionic flow fields for bipolar plates based on leaf venation. Numerical simulations were used to investigate the effect of the number and location of branches, finding out that water removal was improved by a higher number of branches.

Roshandel et al [89] also carried out a research in 2012 based on a numerical model for a new bipolar plate design inspired from the existed biological fluid flow patterns in leafs. Single phase model and constant cell temperature was assumed. The results of the numerical simulations showed that the new design presented a velocity and pressure profiles on catalyst surface were much more uniform, reactant concentration on catalyst surface more homogeneous, and a higher power density than parallel and serpentine flow channels (up to 56\% and $26 \%$ respectively). In a thesis by Warren [90] transparent bipolar plates inspired in leaves were developed in order to investigate the cell performance with a particular focus on water management, also developing a simulation model. Two different designs were analysed, first with constant width channels and secondly with channels where width was varying according to Murray's law. The conventional designs used for benchmarking were a multi-serpentine design and an interdigitated design. The Murray's law design presented the best performance by a significant margin.

Chen et al [91] presented a new work on 2013 with numerical simulations of bipolar plates based on plant vein by means of biomimetic analogy theory. Results showed that performance was influenced by the number and location of the biomimetic flow channel branches, with impact on the outlet velocity. The higher the number of branches, the better was the performance in terms of water removal. The bifurcation principle was used to design the flow field structure by Chen et al [92] in 2013, demonstrating by numerical simulations that a branch flow field 
structure can substantially improve the flow-field distribution, current density and heat transfer with respect to the traditional structure.

The branching structures found in leafs and biological systems were used to investigate flow fields with a similar hierarchical structure by Guo et al [93] in 2014. A series of three designs inspired by the venation structure of a tree leaf were developed and defined by the Murray's law. The designs were compared by both numerical and experimental analyses, where results showed that the bio-inspired interdigitated flow field designs were presenting significantly better polarization curves than the non-interdigitated design, and among them, the design with varying channel width determined by Murray's law was presenting a $20-25 \%$ better performance.

In the work of Saripella et al [94] in 2015 a bio-inspired flow field based on a leaf pattern was experimentally and computationally evaluated. As a novel feature, the experiments were conducted using a transparent cell for direct visualization of liquid water within the channels. The results showed an improved water management and performance characteristics of the bioinspired cell with respect to the conventional one. Murray's law was also applied by Ruan et al [95] in 2016 for the design of a biomimetic flow field configuration, where CFD simulations were carried out in order to compare three different designs (parallel, serpentine and biomimetic channel). The results showed that the flow field designs with biomimetic flow channel performed better than the convectional designs under the same operating conditions. A highly detailed study was carried out by Damian-Ascencio et al [96] in 2017, where four different treelike configurations were considered in a CFD modelling work. It was identified that the number of bifurcations of the vein and their inclination can be considered as parameters. A study of the entropy generation due to mass flow in the new designs was also carried out from the CFD simulation results. They concluded that a better performance in terms of water removal, higher current density and lower entropy production was obtained by increasing the number of bifurcations.

Ozden et al [97] applied the Murray's law to design two different bio-inspired, leaf-shaped flow fields in 2017. Seven different combinations of serpentine, lung, and the two leaf-shaped flow fields were used to assemble different anode-cathode configurations in a DMFC. Experimental work was also carried out. Results showed that the highest performances were achieved when the bio-inspired configurations were used on the cathode side of the cell, where the best configuration was serpentine for the anode and the second leaf design for the cathode. Additional experimental results on DMFC were also obtained by Ouellette et al [98] in 2017, analysing the impact of using bio-inspired interdigitated and non-interdigitated flow fields as anode or cathode plates, using a conventional serpentine flow field as a reference. A 3D numerical model was also developed within the work. The combination of serpentine (anode) and interdigitated (cathode) configuration presented the best performance, which was attributed to the enhanced under-rib convection of both of these flow fields. A sketch of the bioinspired interdigitated is depicted in Figure 6. Non-interdigitated design provided the lowest pressure drop of the examined configurations, although the reactants were prone to travel directly from inlet to outlet causing this design to perform worst. 


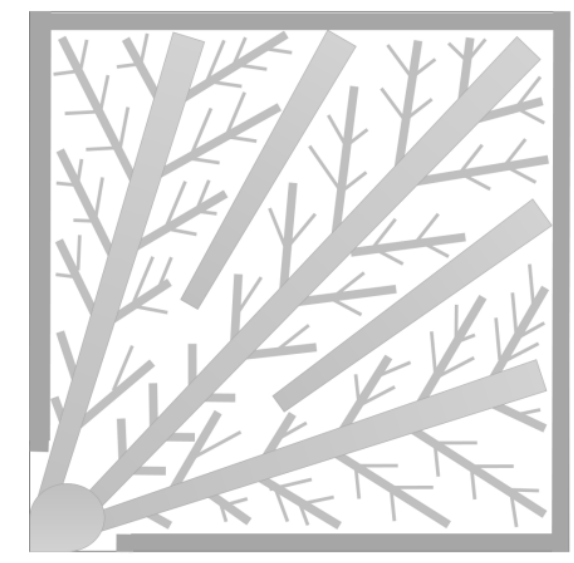

Figure 6. Interdigitated Flow Field design based on tree-like structures, by Ouellette et al [98].

Chen et al [99] presented an asymmetric bionic flow channel in 2017, and showed by numerical simulations that the asymmetrical bionic flow field plate was presenting a lower pressure loss than the conventional flow field. The improvement of the efficiency was attributed to the better and more uniform gas scattering into the different bifurcation channels, as well as to the improved water removal from each branch towards the outlet.

\subsubsection{Lungs}

As it was mentioned in the previous section devoted to leaf designs, Kloess et al [84] also analysed design based on lungs in their work in 2009 for $25 \mathrm{~cm}^{2}$ cells (Figure 7), both by numerical simulations and experimental testing. Lower pressure drop was found also for the lung design, as well as a better (more uniform) gas distribution when compared to conventional designs. Experimental tests revealed that either leaf or lung designs performed better than convectional flow channel design under the same operating conditions, with a peak power density increase of $30 \%$.

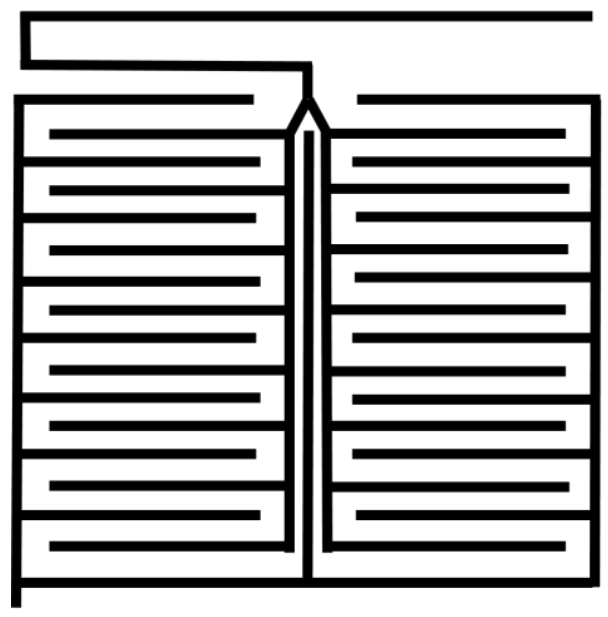

Figure 7. Flow field structure lung-shaped, by Kloess et al [84] 
The work of Ozden et al [97], already mentioned in the previous section devoted to leaf designs, also present prototypes based on lungs for DMFCs. Interestingly, on all the tested configurations the lung-based flow field resulted in the lowest cell performance among the designs tested. Asadzade et al [100] investigated different types of common flow patterns in bipolar plates in 2017, in order to later derive a flow pattern inspired from the human lungs. CFD simulations were carried out modelling the lung-shaped bipolar plate. The simulation results showed that the lung-shaped flow pattern presented the best polarization curve and power density curve with respect to the flow patterns initially analysed.

In the most recent work found for lung-inspired flow fields, Trogadas et al [101] in 2018 applied the fractal geometry of the lung to overcome reactant homogeneity issues. Up to five branching generations were used in the study as depicted in Figure 8, resulting in more uniform reactant distribution and minimum entropy production. A 3D printed $25 \mathrm{~cm}^{2}$ prototype of a lung-inspired flow field with four generations showed a performance improvement with respect to a conventional serpentine flow field. However, pressure drop was diminished for a less number of branches generations.
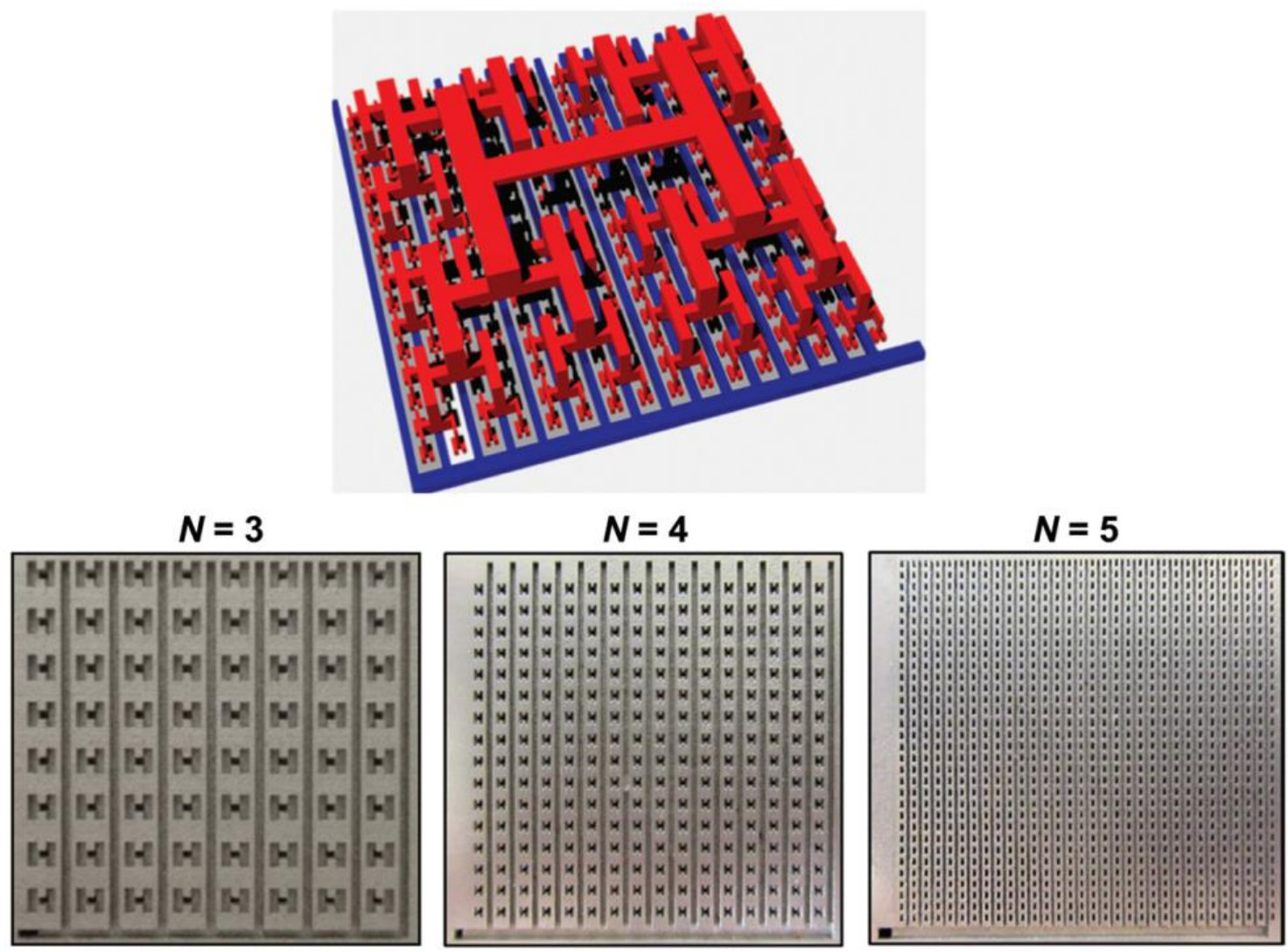

Figure 8. Lung-inspired flow fields by Trogadas et al [101 - Published by The Royal Society of Chemistry] with different number $(\mathrm{N})$ of branching generations.

The lung-inspired, fractal flow-field design was later experimentally analysed by means of Neutron Radiography [102], in order to assess the liquid water content and distributions for different relative humidity values. Although Neutron Radiography is a relatively well-established technique for water visualization in fuel cell research (see for example the work by Owejan [103], Boillat [104] or Manke [105] or Iranzo [106]) it is relevant to mention that this is the first work 
reporting neutron radiographs of fuel cells with biomimetic flow field designs for investigating water management. The results obtained showed that the interdigitated outlet channels of the fractal flow-field with $\mathrm{N}=4$ generations are more prone to present flooding, which was attributed to the slower gas velocity and small channel dimensions. This was considered as the main cause for performance decay at high relative humidity conditions.

\subsubsection{Sponges}

Although not strictly considered as a bio-inspired flow field design in any published work, metal foams have been studied as potential candidates for gas distributors in PEM Fuel Cells, presenting a good potential in terms of performance when compared against traditional designs. Metal foams however could be considered as well as resembling some biological structures such as marine sponges. This review is not intending to provide an exhaustive revision on metal foams or porous materials used in fuel cells, and thus the recent review by Cheong Tan et al [107] from 2018 and the review by Yuan et al. [108] are recommended. The application of metal foam in fuel cells is addressed, discussing the performance benefits. Metal foams, porous metal sinters, metal meshes and perforated metals are included in the review [108].

\subsubsection{Others}

This section is covering design concepts that are not clearly belonging to the previous classification.

Chapman and Mellor from Morgan Group Technology Limited, UK, registered the trademark BioMimetic $^{T M}$ flow field, and presented the design in 2003 [109]. This could be considered as the very first work reported on biomimetic design of bipolar plates (Figure 9). The design was involving larger gross channels to focus the flow, and secondary and ternary tracks to further improve the distribution, together with the use of convoluted barriers and permeable regions.

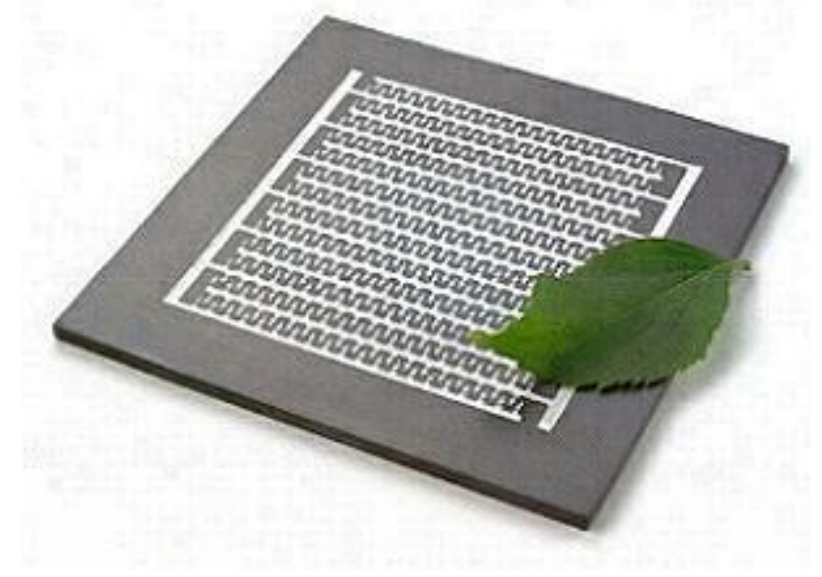

Figure 9. BioMimetic ${ }^{\top \mathrm{M}}$ flow field, by Chapman and Mellor [109].

Several design variations were developed and experimentally tested. CFD modelling was also involved in the design process. It was reported that a 10-16\% increase in the cell peak power could be achieve with respect to a conventional serpentine flow field. Although initially focused on hydrogen PEMFCs, it was stated [110] that the core design was adapted for use in DMFCs as 
well. Morgan also filed a US Patent $(7,067,213$, by Boff et al.) [111] involving flow field plate geometries with branching structures as shown in Figure 10.

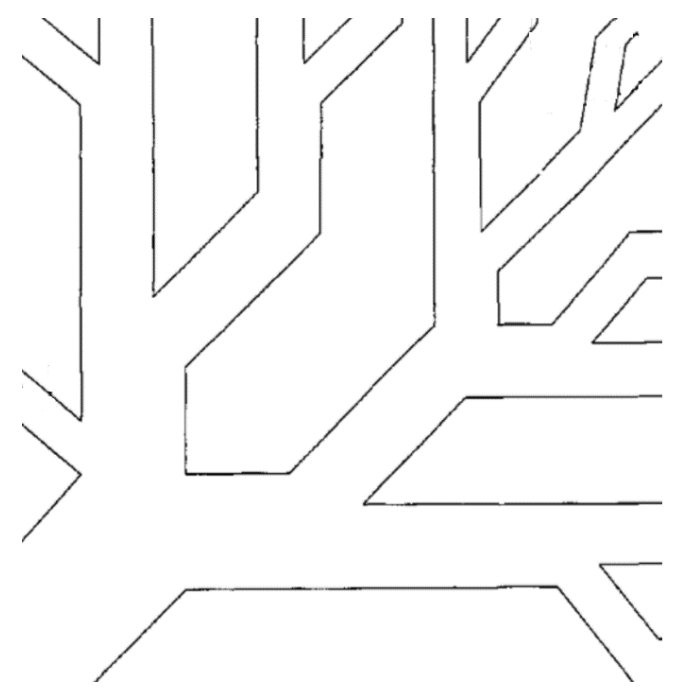

Figure 10. Flow field with branching structure, by Boff et al [111].

Wang et al [112-114] presented several works involving a bionic flow field of a slab-type. In 2009 such design was first proposed by imitating gradual variations of blood vessels in compliance with bionics [112]. Four different design variations (namely bionic flow slab, net flow slab, parallel flow slab and serpentine flow slab) were investigated by flow visualization and simulation analysis. The results showed that the bionic flow slab presented a better performance regarding the flow distribution uniformity and lower pressure drop. Later works on 2010 [113, 114] further elaborated the biomimetic flow slab designs, enhancing oxygen transport and promoting liquid water removal.

In a thesis by Kei Fung in 2010 [115], two design methodologies were used for the redesign of a PEM Fuel Cell, namely biomimetics and the Theory of Inventive Problem Solving (TRIZ). Experimental prototypes were manufactured and tested for water management studies. A set of concepts based on biomimetics were tested, in particular a concept of creating a biomimetic flow field by corrugating the MEA, based on the concept of blood delivery to different locations in the body with soft vessels.

The work of Arvay et al [116] in 2015 presented various biologically inspired flow field designs, that were analysed by means of CFD simulations for Nafion-212 membrane. The CFD model was first validated against experimental results for a single serpentine flow field design. Murray's law was applied for the branching design (Figure 11). The biologically inspired interdigitated design with 9 inlet channels presented a lower pressure drop and enhanced current density distribution compared to all other designs evaluated. 


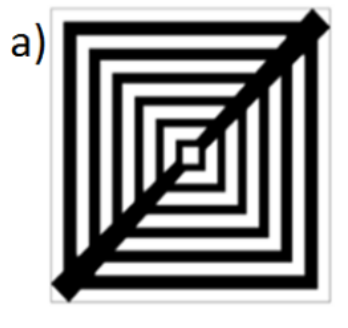

b)

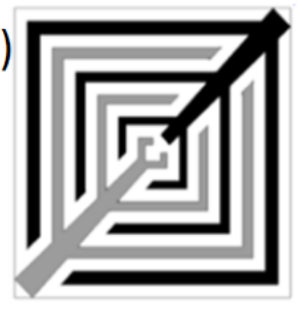

c)

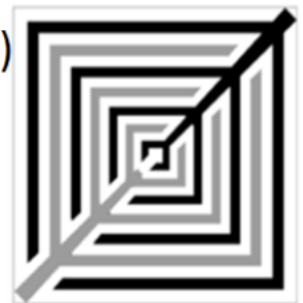

d)

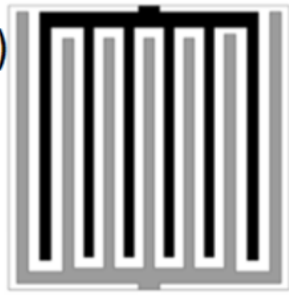

e)

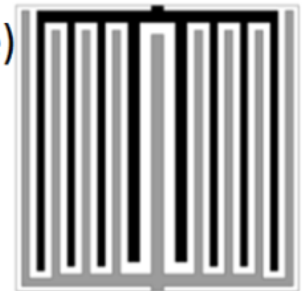

Figure 11. Top: Murray-parallel, (a) Murray-interdigitated-1 (b) and Murray-interdigitated-2 (c). Bottom: pitchfork designs, Pitchfork-7b (d) and Pitchfork-9a (e). Inlet channels are shaded grey and outlet channels are black. By Arvay et al [116].

A set of design principles for creating bio flow fields was developed in a thesis by Heck [117] in 2017. The relative effects of pressure and distribution characteristics of flow fields on fuel cell performance were considered first. Numerical CFD results showed that serpentine flow field performed $17 \%$ better than parallel, where $12 \%$ was due to mass transport effects and $5 \%$ was due to the increase of pressure loss. Bio-inspired designing was then developed for creating new fuel cell flow field concepts. The conclusion was that the greatest area of opportunity for bio designs is when having a minimal pressure loss across the flow field is the dominate design constraint. The CFD simulations of the designed bio flow field showed that the lower pressure losses allowed to produce 2-3 times better power output per pumping power input than the parallel design, while also maintaining better reactant distribution.

A combination of bionics, fractal theory, and Murray's law were employed by Dong-Hiu et al [118] in 2017 for the design of a novel flow field (depicted in Figure 12), based on CFD simulations to investigate the performance. Experimental results were also obtained for model validation. The results showed that the novel flow field presented advantages regarding the uniform distribution of reactants, with a higher power and current density.

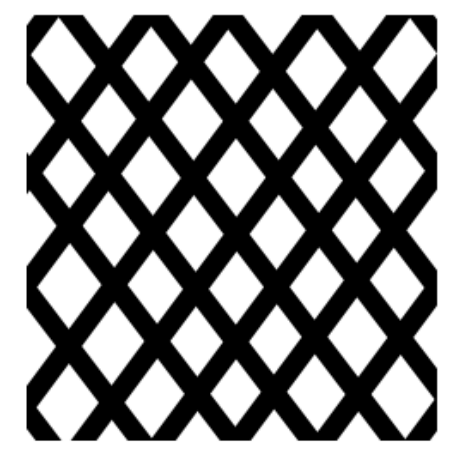

Figure 12. Flow field structure, by Dong-Hiu et al [118] 
Other designs recently presented are based on honeycombs (Atyabi and Afshari [119]), hybrid serpentine-interdigitated (Limjeerajarus and Santiprasertkul [120]) or the designs resulting from applying a topology optimization algorithm (Behrou et al [121]). It is interesting to note that although no assumption was made regarding the flow field layout in the work by Behrou et al [121], so that the optimization algorithm freely evolved along the process, the resulting geometries were significantly resembling biological structures.

\section{Discussion and current status}

A more in-depth discussion of the biomimetic designs identified in the literature is presented in this section, covering a time evolution of the designs, a discussion on the real performance improvements obtained by each design, and a discussion regarding the difficulties in benchmarking the different designs. Manufacturing issues are also briefly discussed.

\subsection{Time evolution of nature inspired design of bipolar plates flow fields}

In order to analyse whether a clear trend in the design of biomimetic flow fields can be derived from the research works reviewed, a time evolution has been represented (Figure 13). The time evolution starts with the early work by Chapman and Mellor [109] in 2003. Apart from the increasing trend in the number of publications along the time, it can be observed that no clear trend in the type of design can be derived from the time analysis. However, it is true that the last work involving fractal structures was published in 2014 by Chang et al [82], and since then the following works have been more focused on leaves and lung-type designs (biologicallyinspired). Considering that fractal structures have not shown any significant performance increase with respect of other designs, the lack of perspectives could be the reason for the lack of recent works on fractal structures applied to bipolar plate designs. However, the extremely high number of potential fractal structures would be indicating that it is very likely that a new, not yet explored, fractal-type bipolar plate could eventually be achieving outstanding performance. In any case, it seems that current research is being more focused on leaf-type and lung-type designs. With the expected increasing amount of research in the next years, it will be possible to better analyse a clearer trend in the evolution of biomimetic designs. 


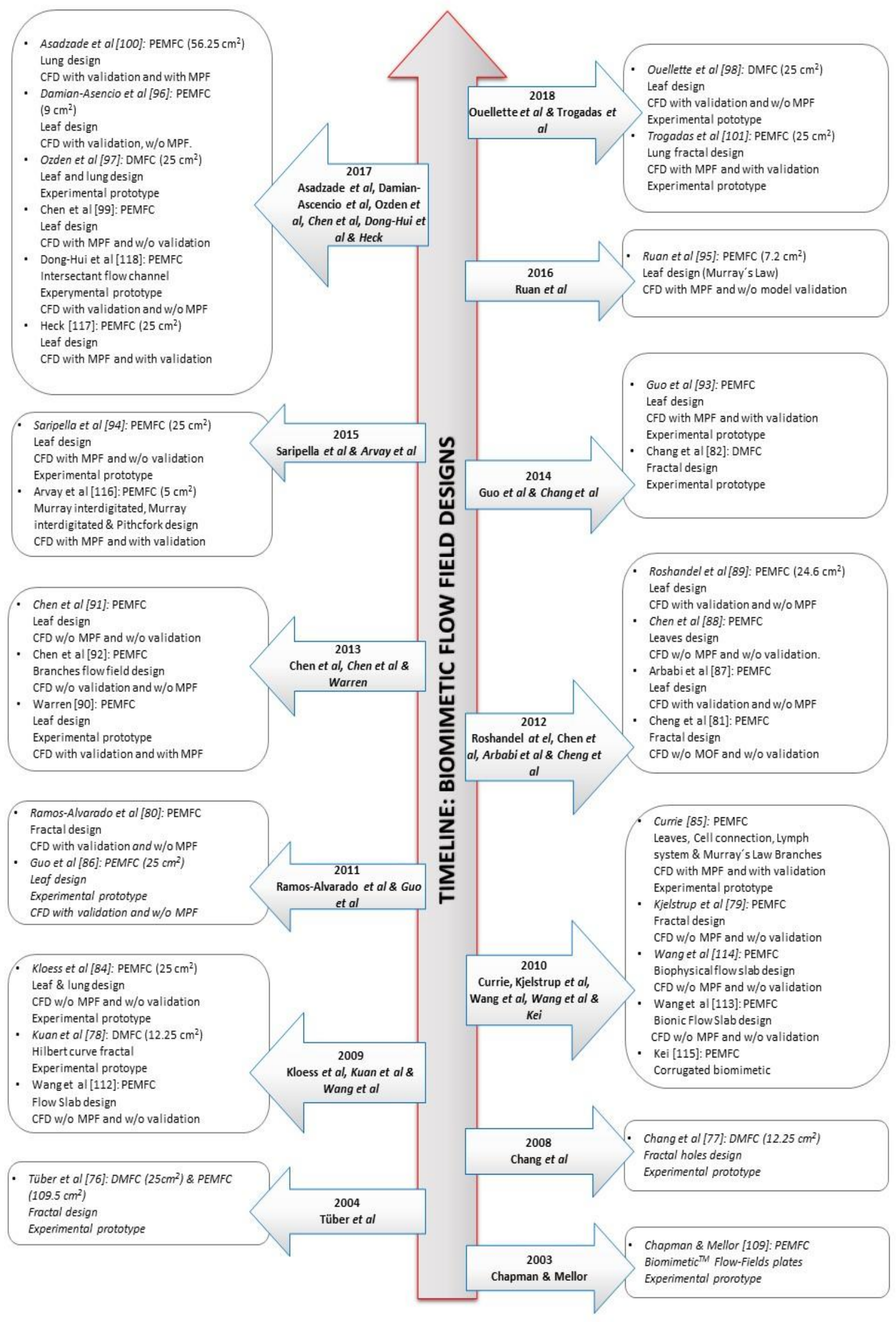

Figure 13. Time evolution of biomimetic Bipolar Plate designs 


\subsection{Critical review on the performance of biologically inspired flow field designs}

An effort has been carried out in order to critically analyse the performance improvements achieved by the different flow field designs. For this, a table with the main features and results of the research works reviewed has been generated and is presented in Table 4 .

The table contains the most relevant information for each design reported. The fuel cell type (hydrogen PEMFC or DMFC) and the Bipolar Plate design are first specified. Then it is indicated whether the study is using CFD techniques for the design and investigation and/or experimental prototypes. In case CFD simulations are reported, it is indicated whether the model was including liquid water transport and its effects, and whether there is a validation of the model. The table also includes the basic information about the cell components being used (membrane, $\mathrm{GDL}$, and catalysts) if available in the original publication. The range of the operating conditions is also provided. Finally, in order to assess the benefits of the novel biomimetic designs, the gain in performance with respect to the conventional designs is indicated in the table. This information has been extracted from the polarization curves reported in the different works. The performance gain is indicated as the current density improvement for the biomimetic bipolar plate with respect to the conventional design, at $0.6 \mathrm{~V}$ (considered to be a nominal point) and at $0.4 \mathrm{~V}$ (more representative of operating conditions at high current densities where the influence of the Bipolar Plate design is much more pronounced). Thus, the value of $\Delta$ performance in Table 4 is determined as the current density at the given voltage in the biomimetic design minus the current density at the given voltage in the conventional design, where both values are determined from the respective polarization curves.

The upper part of Table 4 contains the works presenting experimental prototypes of the biomimetic designs and thus real measurements of the polarization curves. The results reported can be therefore considered as tangible real data of the performance of the biomimetic designs. The experimental techniques being used are also reported in the table, where it can be observed that generally only IV curves are reported. Electrochemical Impedance Spectroscopy (EIS) was only used by Chang et al. [82]. Optical/direct visualization was used by Ozden et al [97] and Warren [90], whereas advanced visualization techniques such as Neutron Radiography has been only used in the recent work by Cho et al. [102]. The second part of Table 4 contains the works that do not report experimental results but instead an investigation based on CFD modelling. The designs based on CFD models where liquid water was included in the modelling and also presenting a model validation are considered in the second section of the table. Additional works based on CFD simulations, however without liquid water modelling and/or experimental validation are included in the final part of Table 4.

Analysing the information provided in the table, it can be observed that in general a relevant performance gain is achieved by the biomimetic designs with respect to the conventional designs, and therefore a significant potential for bio-inspired designs can be demonstrated. Fractal designs have been preferentially applied to DMFCs rather than to hydrogen PEMFCs. The size of the cells used are ranging from $5 \mathrm{~cm}^{2}$ to $110 \mathrm{~cm}^{2}$ (Tüber et al [76]). Among the works with experimental data available for the biomimetic prototypes, the gain in performance is varying significantly, where the highest performance gains for hydrogen PEMFCs (in terms of current density improvement at $0.6 \mathrm{~V}$ and at $0.4 \mathrm{~V}$ ) is showed by the leaf and lung designs by Kloess et al [84], with about $0.4 \mathrm{~A} / \mathrm{cm}^{2}$ to $0.3 \mathrm{~A} / \mathrm{cm}^{2}$ gain at $0.6 \mathrm{~V}$ and $0.4 \mathrm{~V}$ respectively, and Guo et al [93] (leaf design) with $0.35 \mathrm{~A} / \mathrm{cm}^{2}$ gain at $0.4 \mathrm{~V}$. Also Warren [90] reports an improvement of 0.3 $\mathrm{A} / \mathrm{cm}^{2}$ at $0.4 \mathrm{~V}$ for the leaf design. Regarding DMFCs, a significant improvement was reported in the work by Ozden et al [97] for the lung design, and Ouellete et al [98] for the leaf-based design. 
Overall, it could be concluded that within the works reviewed, leaf and lung designs are presenting better potential than designs based on fractals, although the number of works available are not enough at all for ensuring that fractal designs should be discarded in future investigations.

However, when analysing the results in terms of performance, it also must be considered the other cell components used (also indicated in Table 4). As an example, the range of Pt loading in the catalysts reported is between $0.5 \mathrm{mg} \mathrm{Pt} / \mathrm{cm}^{2}$ (as an example in Kloess et al [84]) up to 4 $\mathrm{mg} \mathrm{Pt} / \mathrm{cm}^{2}$ (as in Guo et al [93]) which obviously will make a significant difference in the final performances achieved. This is one of the main difficulties when benchmarking or comparing performance results obtained in the literature as it will be discussed in section 5.3.

\subsection{Benchmarking of nature inspired designs: challenges and opportunities}

When it comes to benchmarking the performance of bipolar plate designs the main difficulty is the lack of a standardization of the cell components. As the catalysts, GDLs, and also operating conditions are different among the works reported in the literature, it is challenging to identify the real or unique influence of the bipolar plate design on the final cell performance reported. This lack of standardization makes very difficult to take advantage of the state-of-the-art knowledge. It would be therefore of a great interest to have available a standard cell or a reference cell, with fully defined geometry and components, and even with a set of polarization curves for defined operating conditions. This would be ideal for a real 1 to 1 comparison of benchmarking, as any future research carried out could assess the performance of the novel design with respect to a well-defined and available reference cell. This would obviously not be limited to bipolar plate biomimetic design, but would be also valid for any kind of bipolar plate design, and any other cell component such as GDL, catalyst, etc. In this sense, it is worth to mention the harmonization initiatives by the European FCH JU (Fuel Cells and Hydrogen Joint Undertaking), where a reference cell is being used within the project ID-FAST [122]. The Joint Research Centre (European Commission) intends to publish not only the project results but also the cell detailed design so that it can be widely used as a reference cell for benchmarking and comparisons (to be published in $\mathrm{FCH}-\mathrm{JU}$ and journal publication). Harmonised operating conditions for fuel cell testing comparison were also published [123]. 
Table 4. Overview of characteristics and performance of biomimetic Bipolar Plate designs

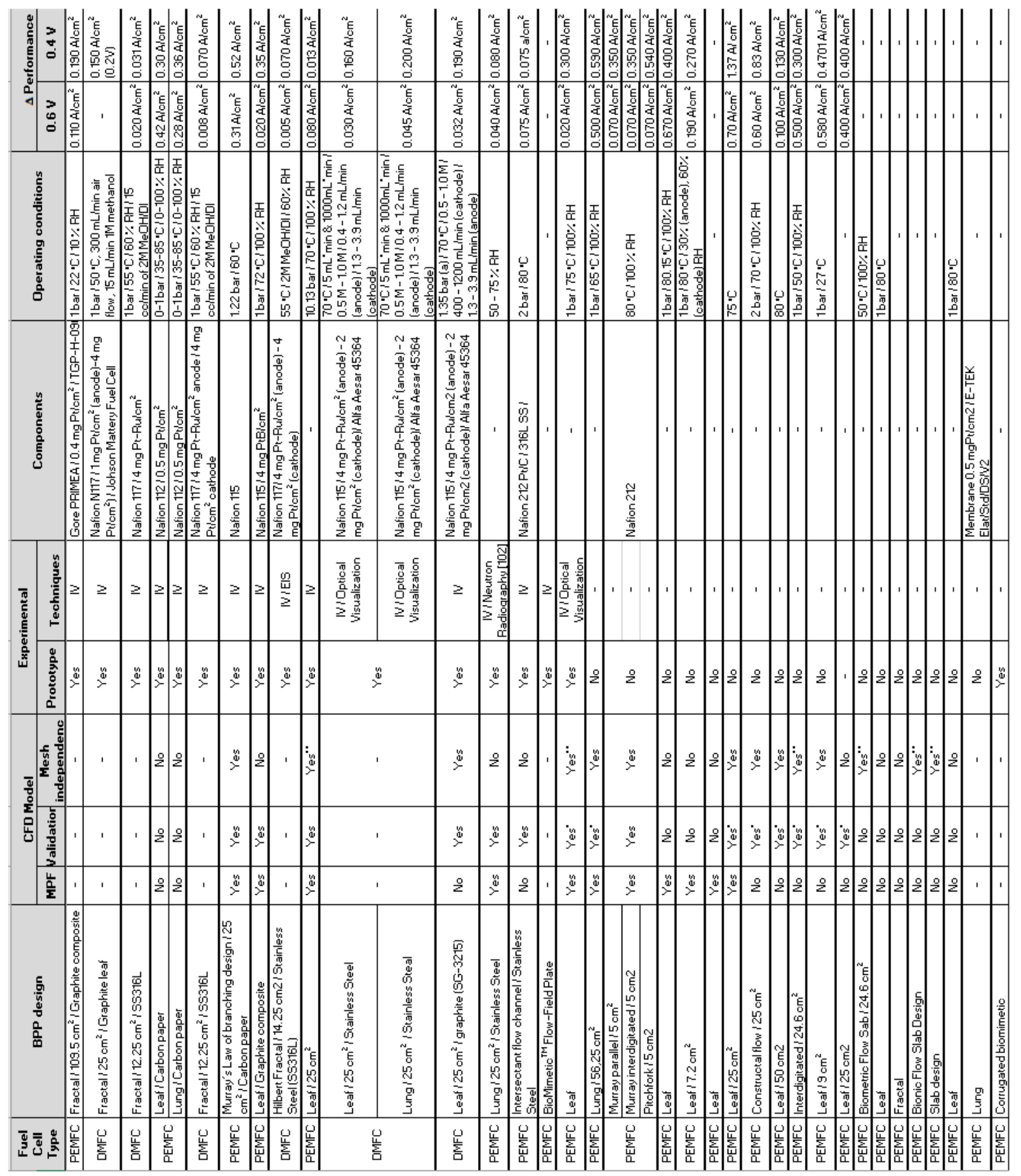

Notes:

1. Fractal design vs. parallel; serpentine design performed better than fractal design.

2. $2^{\text {nd }}$ circular fractal design vs. standard.

3. Bio-inspired vs. interdigitated design.

4. $3^{\text {rd }}$ Hilbert fractal design vs. standard

5. Bio-inspired design vs parallel design.

6. Bio-inspired Design vs. serpentine design.

7. Bio-inspired design vs. interdigitated design.

8. Constructal 256 design vs. constructal 64 design.

* Validation carried out using experimental data from other publications.

** Mesh independence analysis mentioned, but without data/results available. 
Regarding CFD modelling for bipolar plate design, it is required to include multi-phase flow models with an appropriate representation of liquid water transport and effects, and obviously to include appropriate experimental validation of the CFD model. This is particularly relevant when modelling the cell at high current densities where the effect of liquid water is significantly pronounced. Regarding validation, the most appropriate procedure is to carry out the validation against an experimental cell fully defined in terms of component properties and design, where again a reference cell would be very much necessary. In case there is no cell available for testing and thus experimental results from the literature are being used, publications fully reporting the cell components/properties and geometry must be used. As a best practice, common for every CFD model application, a mesh independence study is required.

\subsection{Manufacturing issues and futuristic designs}

As discussed above, there are multiple biomimetic flow field designs of the bipolar plates modelled and simulated for the PEMFC performance in the literature [76-101]. For mass producing bipolar plates, manufacturers should consider a variety of technical and strategic material characteristics like corrosion, durability, freeze-start, heat rejection, power density, weight, cost, recyclability as well as supply chain. The selection of the materials as well as flow field designs are evaluated based on the performance as well as cost-effective manufacturing processes. Table 1 provides the performance, durability and cost targets of the bipolar plates specifically for automotive applications. The U.S. DRIVE Partnership comprising automobile industry, electric utility industry, fuels industry and the U.S. DOE, specifically the Fuel Cell Technical Team developed these targets for assisting the bipolar plate developers and manufacturers in evaluating them without testing full systems. As seen in Table 1, the DOE 2020 cost target for bipolar plate is $\$ 3$ per $\mathrm{kW}$, which was $\sim \$ 7$ per $\mathrm{kW}$ in 2015 [8]. If the target cost of $\$ 3$ per $\mathrm{kW}$ is met, the FC system cost of DOE 2020 target of $\$ 38$ per kW would be achieved in high volume manufacturing. Currently, the BPPs are responsible for $60-85 \%$ of the PEMFC stack weight and 30-50\% of the price [124]. Hence, the cost, weight and volume of FC stacks need to be significantly reduced by an optimum flow field design, flow channel configuration and a scalable manufacturing. In particular, most of the graphite based bipolar plates are being manufactured by relatively slower CNC machining for stationary applications. Moreover, brittleness of graphite plates adds to its fabrication difficulty and hinders its applicability in automotive applications. The high cost also prevents the applicability of this method to highvolume production for automotive fuel cell systems. However, the CNC milling of the mold for high-volume production of metallic plates using methods like stamping would resolve the issues of continuous manufacturing.

Manufacturing metallic BPPs incorporating more complex flow fields enables the production of less expensive and lightweight PEMFC stacks much-improved resistivity to shock and vibration, lower cost and lower fluid cross over. Even though metallic BPPs could be recycled after their lifetime, they do suffer from lower thermal conductivity $(16.3 \mathrm{~W} / \mathrm{m} \mathrm{K})$ compared to graphite composite material (20-50 W/m K) [125]. The complexity of the flow field designs of BPPs hinders their manufacturing by the conventional techniques due to longer throughput times. Hence, it is very important to develop alternative manufacturing technique with a reasonable time and cost for meeting the DOE goals (see Table 1). Rapid-prototyping (RP) consisting of subtractive manufacturing (SM) and additive manufacturing (AM) or 3D printing can be used for fabricating 3D prototypes of BPPs. CNC machining, drilling, milling, grinding and laser-cutting are some typical SMs. AM is highly capable for manufacturing complex designs of biomimetic BBPs 
using metals and alloys for revolutionizing the FC industry compared to SM. However, it remains to be seen if the 3D printed BPP prototypes could be as good as the CNC milled graphite or stamped metallic BPPs in both performance and durability.

The advantage of metallic BBPs over graphitic bipolar plates is the availability and maturity of a large number of cost effective, manufacturing technologies like stamping, compression molding, and engraving. Table 6 below compares various methods currently being explored for manufacturing BPPs for reducing the cost and increasing productivity. Composite plates are cost effective with improved mechanical properties and manufacturability over graphite BBPs, but they suffer from lower electrical conductivity [126].

Table 6. Methods for BPP manufacturing aiming at cost reduction and productivity increase.

\begin{tabular}{|c|c|c|c|c|}
\hline No. & Method & Material & Comment & Ref. \\
\hline 1 & Engraving & Metallic & $\begin{array}{l}\text { Gas supply and water outlet systems, designed to } \\
\text { produce entropy uniformly, have a fractal structure } \\
\text { inspired by the human lung. }\end{array}$ & [127] \\
\hline 2 & SLS & Graphite & $\begin{array}{l}\text { Dimensional shrinkage is a challenge for } \\
\text { geometrical accuracy of channels but is } \\
\text { compensated by scaling-up the initial plate design. }\end{array}$ & [128] \\
\hline 3 & $\begin{array}{l}\text { Electromagnetic } \\
\text { forming }\end{array}$ & SS & $\begin{array}{l}\text { Electromagnetic forming is projected as a better } \\
\text { method over a traditional stamping press. } \\
\text { Commercializing is limited due to coil life and die } \\
\text { wear. }\end{array}$ & [129] \\
\hline 4 & Microforming & SS & $\begin{array}{l}\text { Recent progress of flow field design, microforming } \\
\text { process, joining process and coating process with a } \\
\text { focus in reducing dimensional, shape and assembly } \\
\text { errors summarized. }\end{array}$ & [130] \\
\hline 5 & $\begin{array}{l}\text { Semi-stamp } \\
\text { rubber forming }\end{array}$ & Metallic & $\begin{array}{l}\text { Semi-stamp rubber forming led to improved } \\
\text { dimensional accuracy compared to stamping } \\
\text { method. }\end{array}$ & [131] \\
\hline 6 & Stamping & Metallic & $\begin{array}{l}\text { Need for numerical forming model, feasibility of } \\
\text { new joining/sealing techniques and High } \\
\text { throughput welding techniques for the metallic } \\
\text { bipolar plate highlighted. }\end{array}$ & [132] \\
\hline 7 & $\begin{array}{l}\text { Roller } \\
\text { embossed }\end{array}$ & $\begin{array}{l}\text { Expanded } \\
\text { graphite/resin } \\
\text { composite }\end{array}$ & $\begin{array}{l}\text { Process steps are proven, however immature. } \\
\text { Supply chain is incomplete. However, development } \\
\text { of pilot scale capabilities within supply base is } \\
\text { required for lowering the manufacturing costs. }\end{array}$ & [133] \\
\hline 8 & Stretch forming & SS & $\begin{array}{l}\text { Geometry targets are hard to meet. Large corner } \\
\text { radii, wider channels, wider landings are limited by } \\
\text { the substrate properties and forming technic. }\end{array}$ & [133] \\
\hline 9 & 3D printing & Metallic & $\begin{array}{l}\text { SLA 3D printing is validated for modifying the flow } \\
\text { field design, as well as in validating the simulation } \\
\text { results. }\end{array}$ & [134] \\
\hline 10 & $\begin{array}{l}\text { Powder } \\
\text { metallurgy }\end{array}$ & $\begin{array}{l}\text { Graphite- } \\
\text { 316L SS } \\
\text { composites }\end{array}$ & $\begin{array}{l}\text { Highly resistant to corrosion both in the anode and } \\
\text { cathode. }\end{array}$ & [135] \\
\hline 11 & 3D printing & Metallic & $\begin{array}{l}\text { PEMFC with the 3D cathode flow field with porous } \\
\text { ribs on the bottom is shown to perform much } \\
\text { better compared to that with conventional parallel } \\
\text { straight cathode flow fields, numerically. }\end{array}$ & [136] \\
\hline
\end{tabular}




\subsection{Future work and perspectives}

As it was discussed in section 5.3, a major difficulty when benchmarking the performance of bipolar plate designs is the lack of standardization of the cell components and operating conditions. It is therefore highly complicated to take advantage of the state of the art knowledge included in publications, as each published research is generally using different cell components such as catalysts or GDLs and also different operating conditions. As a future work it would be therefore of a great interest to have a standard cell or a reference cell available with fully defined geometry and components. This would be ideal for a real 1 to 1 comparison of benchmarking, as any future research carried out could assess the performance of the novel design with respect to a well-defined and available reference cell.

Further work involving state-of-the-art CFD modelling considering liquid water formation and transport as well as a more intensive usage of experimental techniques such as Electrochemical Impedance Spectroscopy would be required to further exploit the potential of biomimetic designs. Future work on biomimetic bipolar plate design will continue to rely on CFD simulations but more accurate predictions of the liquid water transport and distributions within the cell will be necessary, as well as a more detailed model validation. Regarding experimental work, techniques such as Electrochemical Impedance Spectroscopy (EIS) have been applied very scarcely to biomimetic designs, where techniques such as Current Density Mapping (CDM) has never been applied to biomimetic designs. It is however clear that more in-depth insights and understandings will be achieved in future works when applying such techniques to biomimetic designs, and the knowledge derived from this will be of major importance for future developments. The same can be said for even more advanced techniques such as X-ray radiography or Neutron radiography, what is expected to provide a much deeper understanding of water management in biomimetic designs.

Regarding design trends and perspectives, it was shown that among both DMFCs and hydrogen PEMFCs, leaf and lung based designs are showing the most promising improvements in terms of performance with respect to conventional designs. Within the works reviewed, designs based on fractals are generally presenting lower performance gains. It must be remarked however that the number of works available are not enough at all for ensuring that fractal designs should be discarded in future investigations.

For the different biomimetic flow fields analysed or to be developed in future, further design variations could provide an even better performance and stability. As an example, channel blockages have been demonstrated to be beneficial in some BPP designs [137, 138], but have been so far never applied to biomimetic concepts. A conceptually similar effect from the one obtained with Murray's law for branching could be obtained with tapered channels. Such design variations have also demonstrated to result in higher cell performances as shown in previous works [139-143], but have also never been applied so far to biomimetic designs.

An additional aspect that will need to be further exploited is the surface wettability of the bipolar plate materials used in the biomimetic designs (hydrophobic/hydrophilic materials/coatings). The nature of the channels surface is representing a relevant role in the cell water management and final performance. Owejan et al. [144] demonstrated that a hydrophobic coating on flow field channels were retaining a higher amount of liquid water. However, Al Shakhshir et al. [145] found out that despite the fact that both hydrophobic or hydrophilic treatment was reducing the overall pressure drop, the cell voltage with a parallel flow field and hydrophilic channels was more stable than that of the untreated channel, and that the hydrophobic treatment was 
decreasing the cell performance. The advantages of hydrophilic channels were shown by Lu et al. [146], where it was found that more uniform water and gas flow distribution and a more desirable film flow regime was achieved by hydrophilically coated gas channels. It is also known that the use of a hydrophilic metal foam in the bipolar plates of the Toyota Mirai has contributed to the improvement in the stack power output [147]. For DMFCs, an ex-situ investigation on the effect of channels with different surface wettability was carried out by Schröder et al. [148], where it was concluded that super-hydrophobic channels had positive effects on the two-phase flow and on performance. However, such studies have never been carried out for biomimetic designs, and therefore future works on biomimetic bipolar plates will need to consider how the surface wettability is influencing water distributions and cell performance in such kind of naturebased designs.

\section{Conclusion}

A review on biomimetic design of Bipolar Plates for Polymer Electrolyte Membrane Fuel Cells (PEMFCS) have been carried out. The review is covering bipolar plate designs based on nature or biological structures such as fractals, leaves, lungs and other structures nature-inspired. It is demonstrated that such biomimetic designs have been explored to date with success since the early introduction of such concept for bipolar plates in 2003, but it can be concluded that biomimetic designs have not yet achieved their full potential. Further work involving state-ofthe-art CFD modelling considering liquid water formation and transport as well as a more intensive usage of experimental techniques such as Electrochemical Impedance Spectroscopy would be required to further exploit the potential of biomimetic designs. A detailed analysis including performance benchmarking and its inherent difficulties due to the current lack of standardization are addressed. A critical review of the performance gain obtained with biomimetic designs reveals that in most cases the biomimetic designs present more efficient water management and higher cell voltages with respect to the conventional designs, and therefore a significant potential for bio-inspired designs can be demonstrated. It was observed that fractal designs have been preferentially applied to DMFCs rather than to hydrogen PEMFCs. Among both DMFCs and hydrogen PEMFCs, leaf and lung based designs are showing the most promising improvements in terms of performance measured are $0.6 \mathrm{~V}$ (representing nominal conditions) and $0.4 \mathrm{~V}$ (representing typical conditions of the mass transport region with higher liquid water content). Within the works reviewed, designs based on fractals are generally presenting lower performance gains, although the number of works available are not enough at all for ensuring that fractal designs should be discarded in future investigations.

\section{Acknowledgments}

This work has been developed under the funding of the Spanish Ministry of Science, Innovation and Universities, project funded reference ENE2017-91159-EXP (Bio-inspired designs for bipolar plates of PEM Fuel Cells with optimized water management), and the Spanish Ministry of Economy and Competitiveness, grant UNSE15-CE2962 (Characterization and optimization of fuel cells for their integration in mobile and stationary applications) co-funded with European Regional Development Fund (ERDF). 
C. H. Arredondo acknowledges the grant from the Government of Mexico through the National Coordination of Higher Education Scholarship supporting the program "International Mobility 2018".

\section{Appendix A}

Two recently published articles are briefly discussed.

Kang et al. [149] has presented an experimental study of $25 \mathrm{~cm}^{2}$ with leaf veins bipolar plates compared against serpentine and parallel flow fields. The power density obtained with the ginkgo flow field was still $7 \%$ lower than that for the serpentine flow field, but this was achieved with only $3 \%$ of the pumping power required by the serpentine. Thus the usable power density for the ginkgo flow field was the highest among all designs tested.

Liu et al. [150] carried out an investigation using both numerical simulations and experimental measurements on bionic flow fields, where symmetric and asymmetric bionic flow channels were analysed under gravity (channel orientations). VOF model was used for the multiphase simulation of water distributions, whereas a $25 \mathrm{~cm}^{2}$ cell was used for the experimental testing. Gravity has shown to play a significant effect on the liquid water transport and on the cell performance of the cell.

\section{References}

[1] A. Arvay, J. French, J.-C. Wang, X.-H Peng, A. M. Kannan. Nature inspired flow field designs for proton exchange membrane fuel cell. International Journal of Hydrogen Energy 2013; 38: 3717-3726

[2] Li, X., Sabir, I. Review of bipolar plates in PEM fuel cells: Flow-field designs. International Journal of Hydrogen Energy 2005; 30(4), pp. 359-371.

[3] Hermann, A., Chaudhuri, T., Spagnol, P. Bipolar plates for PEM fuel cells: A review. International Journal of Hydrogen Energy 2005; 30(12), pp. 1297-1302

[4] Mehta, V., Cooper, J.S. Review and analysis of PEM fuel cell design and manufacturing. Journal of Power Sources 2003; 114(1), pp. 32-53

[5] Li, H., Tang, Y., Wang, Z., Shi, Z., Wu, S., Song, D., Zhang, J., Fatih, K., Zhang, J., Wang, H., Liu, $Z$, Abouatallah, R., Mazza, A. A review of water flooding issues in the proton exchange membrane fuel cell. Journal of Power Sources 2008; 178(1), pp. 103-117

[6] Borup, R., Meyers, J., Pivovar, B., Kim, Y-S., Mukundan, R., Garland, N., Myers, D., Wilson, M., Garzon, F., Wood, D., Zelenay, P., More, K., Stroh, K., Zawodzinski, T., Boncella, J., McGrath, J.E., Inaba, M., Miyatake, K., Hori, M., Ota, K., Ogumi, Z., Miyata, S., Nishikata, A., Siroma, Z., Uchimoto, Y., Yasuda, K., Kimijima, K.-I., Iwashita, N. Scientific aspects of polymer electrolyte fuel cell durability and degradation. Chemical Reviews 2007; 107(10), pp. 3904-3951

[7] Wu, J., Yuan, X.Z., Martin, J.J., Wang, H., Zhang, J., Shen, J. Wu, S., Merida, W. A review of PEM fuel cell durability: Degradation mechanisms and mitigation strategies. Journal of Power Sources 2008; 184(1), pp. 104-119 
[8] DOE, 2013. Fuel Cell Technologies Office Multi-Year Research, Development, and Demonstration (MYRD\&D) Plan. U.S. Department of Energy, Washington, D.C.

[9] Hamilton, P.J., Pollet, B.G. Polymer electrolyte membrane fuel cell (PEMFC) flow field plate: Design, materials and characterization. Fuel Cells, 2010; 10(4), pp. 489-509

[10] Mahabunphachai, S., Cora, O.N., Koç, M. Effect of manufacturing processes on formability and surface topography of proton exchange membrane fuel cell metallic bipolar plates. Journal of Power Sources. 2010; 195(16), pp. 5269-5277

[11] Peng, L., Yi, P., Lai, X. Design and manufacturing of stainless steel bipolar plates for proton exchange membrane fuel cells. International Journal of Hydrogen Energy, 2014; 39(36), pp. 21127-21153

[12] Kumar, A., Reddy, R.G. Effect of channel dimensions and shape in the flow-field distributor on the performance of polymer electrolyte membrane fuel cells. Journal of Power Sources, 2003; 113(1), pp. 11-18

[13] Hontañón, E., Escudero, M.J., Bautista, C., García-Ybarra, P.L., Daza, L. Optimization of flowfield in polymer electrolyte membrane fuel cells using computational fluid dynamics techniques. Journal of Power Sources, 2000; 86(1), pp. 363-368

[14] Wang, X.-D., Duan, Y.-Y., Yan, W.-M., Peng, X.-F. Local transport phenomena and cell performance of PEM fuel cells with various serpentine flow field designs. Journal of Power Sources, 2008; 175(1), pp. 397-407

[15] Spernjak, D., Prasad, A.K., Advani, S.G. In situ comparison of water content and dynamics in parallel, single-serpentine, and interdigitated flow fields of polymer electrolyte membrane fuel cells. Journal of Power Sources, 2010; 195(11), pp. 3553-3568

[16] Taccani, R., Zuliani, N. Effect of flow field design on performances of high temperature PEM fuel cells: Experimental analysis. International Journal of Hydrogen Energy, 2011; 36(16), pp. 10282-10287

[17] Iranzo, A., Muñoz, M., López, E., Pino, J., Rosa, F. Experimental fuel cell performance analysis under different operating conditions and bipolar plate designs. International Journal of Hydrogen Energy, 2010; 35(20), pp. 11437-11447

[18] Wang, J., Wang, H.Flow-field designs of bipolar plates in PEM fuel cells: Theory and applications. Fuel Cells, 2012; 12(6), pp. 989-1003

[19] Birgersson, E., Vynnycky, M. A quantitative study of the effect of flow-distributor geometry in the cathode of a PEM fuel cell. Journal of Power Sources, 2006; 153(1), pp. 76-88

[20] Meenakshi, S., Ghosh, P.C. Study of an Innovative Versatile Flow Design Suitable for Fuel Cells. Journal of Electrochemical Energy Conversion and Storage, 2017; 14(4),041003

[21] Alaefour, I., Karimi, G., Jiao, K., Shakhshir, S.A., Li, X. Experimental study on the effect of reactant flow arrangements on the current distribution in proton exchange membrane fuel cells. Electrochimica Acta, 2011; 56(5), pp. 2591-2598

[22] Alaefour, I., Karimi, G., Jiao, K., Li, X. Measurement of current distribution in a proton exchange membrane fuel cell with various flow arrangements - A parametric study. Applied Energy, 2012; 93, pp. 80-89 
[23] Iranzo, A., Biesdorf, J., Cochet, M., Salva, A., Boillat, P., Rosa, F. Effect of Serpentine Multipass Flow Field Channel Orientation in the Liquid Water Distributions and Cell Performance. Fuel Cells, 2016; 16(6), pp. 777-783

[24] Kramer, D., Zhang, J., Shimoi, R., Lehmann, E., Wokaun, A., Shinohara, K., Scherer, G.G. In situ diagnostic of two-phase flow phenomena in polymer electrolyte fuel cells by neutron imaging: Part A. Experimental, data treatment, and quantification. Electrochimica Acta, 2005; 50 (13), pp. 2603-2614.

[25] Iranzo, A., Boillat, P., Biesdorf, J., Tapia, E., Salva, A., Guerra, J. Liquid water preferential accumulation in channels of PEM fuel cells with multiple serpentine flow fields. International Journal of Hydrogen Energy, 2014; 39 (28), pp. 15687-15695

[26] Lee, J.-C., Shay, T., Chang, S.-K. Orientation-dependent performance of portable proton exchange membrane fuel cells. Journal of Fuel Cell Science and Technology, 2011; 8 (3), art. no. 031007.

[27] Morin, A., Xu, F., Gebel, G., Diat, O. Influence of PEMFC gas flow configuration on performance and water distribution studied by SANS: Evidence of the effect of gravity. International Journal of Hydrogen Energy, 2011; 36 (4), pp. 3096-3109.

[28] Manso A. P., Marzo F. F., Mujica M. G., Barranco J., Lorenzo A. Numerical analysis of the influence of the cannel cross-section aspect ratio on the performance of a PEM Fuel Cell with serpentine flow field design. Journal of Hydrogen Energy 2011; 36: 6795-6808

[29] Shimpalee, S., Van Zee, J.W. Numerical studies on rib \& channel dimension of flow-field on PEMFC performance. International Journal of Hydrogen Energy, 2007; 32(7), pp. 842-856

[30] Peng, L., Lai, X., Liu, D., Hu, P., Ni, J. Flow channel shape optimum design for hydroformed metal bipolar plate in PEM fuel cell. Journal of Power Sources, 2008; 178(1), pp. 223-230

[31] Manso, A.P., Marzo, F.F., Barranco, J., Garikano, X., Garmendia Mujika, M. Influence of geometric parameters of the flow fields on the performance of a PEM fuel cell. A review 2012 International Journal of Hydrogen Energy 37(20), pp. 15256-15287

[32] Heidary, H., Kermani, M.J., Dabir, B. Influences of bipolar plate channel blockages on PEM fuel cell performances. Energy Conversion and Management, 2016; 124, pp. 51-60

[33] Hermann, A., Chaudhuri, T., Spagnol, P. Bipolar plates for PEM fuel cells: A review. International Journal of Hydrogen Energy, 2005; 30(12), pp. 1297-1302

[34] Wang, H., Sweikart, M.A., Turner, J.A. Stainless steel as bipolar plate material for polymer electrolyte membrane fuel cells. Journal of Power Sources, 2003; 115(2), pp. 243-251

[35] Tawfik, H., Hung, Y., Mahajan, D. Metal bipolar plates for PEM fuel cell-A review. Journal of Power Sources, 2007; 163(2), pp. 755-767

[36] Antunes, R.A., Oliveira, M.C.L., Ett, G., Ett, V. Corrosion of metal bipolar plates for PEM fuel cells: A review. International Journal of Hydrogen Energy, 2010; 35(8), pp. 3632-3647

[37] Mandal, P., Kumar Chanda, U., Roy, S. A review of corrosion resistance method on stainless steel bipolar plate. Materials Today: Proceedings, 2018; 5(9), pp. 17852-17856 
[38] Asri, N.F., Husaini, T., Sulong, A.B., Majlan, E.H., Daud, W.R.W. Coating of stainless steel and titanium bipolar plates for anticorrosion in PEMFC: A review. International Journal of Hydrogen Energy, 2017; 42(14), pp. 9135-9148

[39] Wang, H., Turner, J.A. Reviewing metallic PEMFC bipolar plates. Fuel Cells, 2010; 10(4), pp. 510-519

[40] Wang, C.-Y. Fundamental models for fuel cell engineering. Chemical Reviews, 2004; 104(10), pp. 4727-4765

[41] Djilali, N. Computational modelling of polymer electrolyte membrane (PEM) fuel cells: Challenges and opportunities. Energy, 2007; 32(4), pp. 269-280

[42] Ma, L., Ingham, D.B., Pourkashanian, M., Carcadea, E. Review of the computational fluid dynamics modeling of fuel cells. Journal of Fuel Cell Science and Technology, 2005; 2(4), pp. 246-257

[43] Siegel, C. Review of computational heat and mass transfer modeling in polymer-electrolytemembrane (PEM) fuel cells. Energy, 2008; 33(9), pp. 1331-1352

[44] Litterst, C., Eccarius, S., Hebling, C., Zengerle, R., Koltay, P. Increasing $\mu \mathrm{dMFC}$ efficiency by passive $\mathrm{CO} 2$ bubble removal and discontinuous operation. Journal of Micromechanics and Microengineering, 2006; 16(9),S12, pp. S248-S253

[45] Wang, S.-J., Huo, W.-W., Zou, Z.-Q., Qiao, Y.-J., Yang, H. Computational simulation and experimental evaluation on anodic flow field structures of micro direct methanol fuel cells. Applied Thermal Engineering, 2011; 31(14-15), pp. 2877-2884

[46] Baek, S.M., Yu, S.H., Nam, J.H., Kim, C.-J. A numerical study on uniform cooling of large-scale PEMFCs with different coolant flow field designs. Applied Thermal Engineering, 2011; 31(8-9), pp. 1427-1434

[47] Shimpalee, S. Dynamic simulation of large scale PEM fuel cell under driving cycle. Journal of the Electrochemical Society, 2014; 161(8), pp. E3138-E3148

[48] Zhang, G., Xie, X., Xie, B., Du, Q., Jiao, K. Large-scale multi-phase simulation of proton exchange membrane fuel cell. International Journal of Heat and Mass Transfer, 2019; 130, pp. $555-563$

[49] Shimpalee, S., Ohashi, M., Van Zee, J.W., (...), Sadeler, C., Hebling, C. Experimental and numerical studies of portable PEMFC stack. Electrochimica Acta, 2009; 54(10), pp. 2899-2911

[50] Shan, Y., Choe, S.-Y. Modeling and simulation of a PEM fuel cell stack considering temperature effects. Journal of Power Sources, 2006; 158(1), pp. 274-286

[51] Chen, C.-H., Jung, S.-P., Yen, S.-C. Flow distribution in the manifold of PEM fuel cell stack. Journal of Power Sources, 2007; 173(1), pp. 249-263

[52] Zamel, N., Li, X. Effective transport properties for polymer electrolyte membrane fuel cells - With a focus on the gas diffusion layer. Progress in Energy and Combustion Science, 2013; 39(1), pp. 111-146

[53] Zhang, G., Jiao, K. Multi-phase models for water and thermal management of proton exchange membrane fuel cell: A review. Journal of Power Sources, 2018; 391, pp. 120-133 
[54] Bazylak, A. Liquid water visualization in PEM fuel cells: A review. International Journal of Hydrogen Energy, 2009; 34(9), pp. 3845-3857

[55] Tsushima, S., Hirai, S. In situ diagnostics for water transport in proton exchange membrane fuel cells. Progress in Energy and Combustion Science, 2011; 37(2), pp. 204-220

[56] Weber, A.Z., Hickner, M.A. Modeling and high-resolution-imaging studies of water-content profiles in a polymer-electrolyte-fuel-cell membrane-electrode assembly. Electrochimica Acta, 2008; 53 (26), pp. 7668-7674.

[57] Wang, Y., Chen, K.S. Through-plane water distribution in a polymer electrolyte fuel cell: Comparison of numerical prediction with neutron radiography data. Journal of the Electrochemical Society, 2010; 157 (12), pp. B1878-B1886.

[58] Iranzo, A., Boillat, P., Rosa, F. Validation of a three dimensional PEM fuel cell CFD model using local liquid water distributions measured with neutron imaging. International Journal of Hydrogen Energy, 2014; 39(13), pp. 7089-7099

[59] Quan, P., Lai, M.-C. PEM fuel cell water transport - Simulation and neutron imaging experiment. ECS Transactions, 2010; 26 (1), pp. 179-196.

[60] Arvay, A., Ahmed, A., Peng, X.-H., Kannan, A.M. Convergence criteria establishment for 3D simulation of proton exchange membrane fuel cell. International Journal of Hydrogen Energy, 2012; 37(3), pp. 2482-2489

[61] Bednarek, T., Tsotridis, G. Issues associated with modelling of proton exchange membrane fuel cell by computational fluid dynamics. Journal of Power Sources, 2017; 343, pp. 550-563

[62] Macedo-Valencia, J., Sierra, J.M., Figueroa-Ramírez, S.J., Díaz, S.E., Meza, M. 3D CFD modeling of a PEM fuel cell stack. International Journal of Hydrogen Energy (2016); 41(48), pp. 23425-23433

[63] Ahmadi, N., Dadvand, A., Rezazadeh, S., Mirzaee, I. Analysis of the operating pressure and GDL geometrical configuration effect on PEM fuel cell performance. Journal of the Brazilian Society of Mechanical Sciences and Engineering (2016); 38(8), pp. 2311-2325

[64] Penga, Ž., Tolj, I., Barbir, F. Computational fluid dynamics study of PEM fuel cell performance for isothermal and non-uniform temperature boundary conditions. International Journal of Hydrogen Energy (2016); 41(39), pp. 17585-17594

[65] Osanloo, B., Mohammadi-Ahmar, A., Solati, A. A numerical analysis on the effect of different architectures of membrane, $\mathrm{CL}$ and GDL layers on the power and reactant transportation in the square tubular PEMFC. International Journal of Hydrogen Energy (2016); 41(25), pp. 1084410853

[66] Choopanya, P., Yang, Z. An effective mesh strategy for CFD modelling of polymer electrolyte membrane fuel cells. International Journal of Hydrogen Energy (2016); 41(15), pp. 6445-6456

[67] Ghanbarian, A., Kermani, M.J. Enhancement of PEM fuel cell performance by flow channel indentation. Energy Conversion and Management (2016): 110, pp. 356-366

[68] Iranzo, A., Muñoz, M., Rosa, F., Pino, J. Numerical model for the performance prediction of a PEM fuel cell. Model results and experimental validation. International Journal of Hydrogen Energy, 2010; 35 (20), pp. 11533-11550 
[69] Ozden, E., Tari, I. Proton exchange membrane fuel cell degradation: A parametric analysis using Computational Fluid Dynamics. Journal of Power Sources (2016); 304, pp. 64-73

[70] Rezazadeh, S., Ahmadi, N. Numerical investigation of gas channel shape effect on proton exchange membrane fuel cell performance. Journal of the Brazilian Society of Mechanical Sciences and Engineering (2015); 37(3), pp. 789-802

[71] Torkavannejad, A., Pesteei, M., Khalilian, M., Ramin, F., Mirzaee, I. Effect of deflected membrane electrode assembly on species distribution in PEMFC. International Journal of Engineering, Transactions A: Basics (2015); 28(3), pp. 467-475

[72] Choopanya, P., Yang, Z. An effective mesh strategy for CFD modelling of polymer electrolyte membrane fuel cells. International Journal of Hydrogen Energy, 2016; 41(15), pp. 6445-6456

[73] Jeon, D.H., Greenway, S., Shimpalee, S., Van Zee, J.W. The effect of serpentine flow-field designs on PEM fuel cell performance. International Journal of Hydrogen Energy, 2008; 33(3), pp. 1052-1066

[74] Iranzo, A., Muñoz, M., Pino, J., Rosa, F. Update on numerical model for the performance prediction of a PEM Fuel Cell. International Journal of Hydrogen Energy, 2011; 36(15), pp. 9123 9127

[75] Limjeerajarus, N., Charoen-Amornkitt, P. Effect of different flow field designs and number of channels on performance of a small PEFC. International Journal of Hydrogen Energy, 2015; 40(22), pp. 7144-7158

[76] Tüber, K., Oedegaard, A., Hermann, M., Hebling, C. Investigation of fractal flow-fields in portable proton exchange membrane and direct methanol fuel cells. Journal of Power Sources (2004); 131(1-2), pp. 175-181

[77] Chang, J.-Y., Kuan, Y.-D., Lee, S.-M., Lee, S.-R. Characterization of a liquid feed direct methanol fuel cell with Sierpinski carpets fractal current collectors. Journal of Power Sources (2008); 184(1), pp. 180-190

[78] Kuan, Y.-D., Chang, J.-Y., Lee, S.-M., Lee, S.-R. Characterization of a direct methanol fuel cell using Hilbert curve fractal current collectors. Journal of Power Sources (2009); 187(1), pp. 112122

[79] Kjelstrup, S., Coppens, M.-O., Pharoah, J.G., Pfeifer, P. Nature-inspired energy-and materialefficient design of a polymer electrolyte membrane fuel cell. Energy and Fuels (2010); 24(9), pp. 5097-5108

[80] Ramos-Alvarado, B., Hernandez-Guerrero, A., Elizalde-Blancas, F., Ellis, M.W. Constructal flow distributor as a bipolar plate for proton exchange membrane fuel cells. International Journal of Hydrogen Energy (2011); 36(20), pp. 12965-12976

[81] S. J. Cheng et al., "Numerical Simulation Applied to Study the Effects of Fractal Tree-Liked Network Channel Designs on PEMFC Performance", Advanced Materials Research (2012), Vols. 488-489, pp. 1219-1223.

[82] Chang, J.-Y., Kuan, Y.-D., Lee, S.-M. Experimental investigation of a direct methanol fuel cell with Hilbert fractal current collectors. Journal of Chemistry (2014); 371616 
[83] Sherman, T.F. On connecting large vessels to small. The meaning of Murray's law. J. Gen. Physiol., 1981, 78, 431-453

[84] Kloess, J.P., Wang, X., Liu, J., Shi, Z., Guessous, L. Investigation of bio-inspired flow channel designs for bipolar plates in proton exchange membrane fuel cells. Journal of Power Sources (2009); 188(1), pp. 132-140

[85] Jessica Marie Currie. Biomimetic Design Applied to the Redesign of a PEM Fuel Cell Flow Field. Thesis; 2010

[86] Guo N., Leu M. C., Wu M. Bio-inspired design of bipolar plate flow fields for polymer electrolyte membrane fuel cells. Proc. SFF Symposium, (2011) pp. 607-623

[87] F. Arbabi, R. Roshandel, G. Karimi Moghaddam. Numerical Modeling of an Innovative Bipolar Plate Design Based on the Leaf Venation Patterns for PEM Fuel Cells. International Journal of Engineering (2012); 25(3), pp. 177-186

[88] Chen, T., Xiao, Y., Chen, T. The impact on PEMFC of bionic flow field with a different branch. Energy Procedia (2012); 28, pp. 134-139

[89] Roshandel, R., Arbabi, F., Moghaddam, G.K. Simulation of an innovative flow-field design based on a bio inspired pattern for PEM fuel cells. Renewable Energy (2012); 41, pp. 86-95

[90] Freer, Nicholas Warren, "Water management capabilities of bio-inspired flow field configurations for polymer electrolyte membrane fuel cells" (2013). Masters Theses. 5388.

[91] Chen, T., Liu, S., Gong, S., Wu, C. Development of bipolar plates with different flow channel configurations based on plant vein for fuel cell. International Journal of Energy Research (2013); 37(13), pp. $1680-1688$

[92] Chen, T., Gong, S.-C., Xiao, Y. Investigation of bifurcation structure flow field for bipolar plates in PEMFC. Heat and Mass Transfer/Waerme- und Stoffuebertragung (2013); 49(2), pp. 147-153

[93] Guo, N., Leu, M.C., Koylu, U.O. Bio-inspired flow field designs for polymer electrolyte membrane fuel cells. International Journal of Hydrogen Energy (2014); 39(36)

[94] Saripella, B.P., Koylu, U.O., Leu, M.C. Experimental and computational evaluation of performance and water management characteristics of a bio-inspired proton exchange membrane fuel cell. Journal of Fuel Cell Science and Technology (2015); 12(6), 061007

[95] Ruan, H., Wu, C., Liu, S., Chen, T. Design and simulation of novel flow field plate geometry for proton exchange membrane fuel cells. Heat and Mass Transfer/Waerme- und Stoffuebertragung (2016); 52(10), pp. 2167-2176

[96] Damian-Ascencio, C.E., Saldaña-Robles, A., Hernandez-Guerrero, A., Cano-Andrade, S. Numerical modeling of a proton exchange membrane fuel cell with tree-like flow field channels based on an entropy generation analysis. Energy (2017); 133, pp. 306-316

[97] Ozden, A., Ercelik, M., Ouellette, D., Colpan, C. O., Ganjehsarabi, H., Hamdullahpur, F. Designing, modeling and performance investigation of bio-inspired flow field based DMFCs. International Journal of Hydrogen Energy (2017); 42(33), pp. 21546-21558

[98] Ouellette, D., Ozden, A., Ercelik, M., Colpan, C. O., Ganjehsarabi, H., Li, X., Hamdullahpur, F. Assessment of different bio-inspired flow fields for direct methanol fuel cells through 3D 
modeling and experimental studies. International Journal of Hydrogen Energy (2018); 43(2), pp. $1152-1170$

[99] Chen, T., Liu, S., Yang, L. Development of flow field plates based on asymmetric leaf structure for PEM fuel cell. International Journal of Materials and Structural Integrity (2017); 11(4), pp. 229-243

[100] Asadzade, M., Shamloo, A. Design and simulation of a novel bipolar plate based on lungshaped bio-inspired flow pattern for PEM fuel cell. International Journal of Energy Research (2017); 41(12), pp. 1730-1739

[101] Trogadas, P., Cho, J.I.S., Neville, T.P., Marquis, J., Wu, B., Brett, D.J.L., Coppens, M.-O. A lung-inspired approach to scalable and robust fuel cell design. Energy and Environmental Science (2018); 11(1), pp. 136-143

[102] Cho, J.I.S., Neville, T.P., Trogadas, P., Meyer, Q., Wu, Y., Ziesche, R., Boillat, P., Cochet, M., Manzi-Orezzoli, V., Shearing, P., Brett, D.J.L., Coppens, M.-O. Visualization of liquid water in a lung-inspired flow-field based polymer electrolyte membrane fuel cell via neutron radiography. Energy (2019); 170, pp. 14-21

[103] Owejan, J.P., Trabold, T.A., Jacobson, D.L., Arif, M., Kandlikar, S.G. Effects of flow field and diffusion layer properties on water accumulation in a PEM fuel cell. International Journal of Hydrogen Energy, 2007; 32(17), pp. 4489-4502

[104] Boillat, P., Kramer, D., Seyfang, B.C., (...), Tasaki, Y., Shinohara, K. In situ observation of the water distribution across a PEFC using high resolution neutron radiography. Electrochemistry Communications, 2008; 10(4), pp. 546-550

[105] Hartnig, C., Manke, I., Kuhn, R., (...), Goebbels, J., Banhart, J. High-resolution in-plane investigation of the water evolution and transport in PEM fuel cells. Journal of Power Sources, 2009; 188(2), pp. 468-474

[106] Iranzo, A., Boillat, P., Biesdorf, J., Salva, A. Investigation of the liquid water distributions in a $50 \mathrm{~cm} 2$ PEM fuel cell: Effects of reactants relative humidity, current density, and cathode stoichiometry. Energy, 2015; 82, pp. 914-921

[107] Tan, W.C., Saw, L.H., Thiam, H.S., Xuan, J., Cai, Z., Yew, M.C. Overview of porous media/metal foam application in fuel cells and solar power systems. Renewable and Sustainable Energy Reviews (2018); 96, pp. 181-197

[108] Yuan, W., Tang, Y., Yang, X., Wan, Z. Porous metal materials for polymer electrolyte membrane fuel cells - A review. Applied Energy, 2012; 94, pp. 309-329

[109] Chapman A. R., Mellor I. M. Development of BioMimetic ${ }^{\top M}$ Flow-Field Plates for PEM Fuel Cell. Eighth Grove Fuel Cell symposium, 2003.

[110] Fuel Cells Bulletin, 2003 (11), Biomimetic bipolar plate boosts power, cuts cost. DOI: https://doi.org/10.1016/S1464-2859(03)01107-6

[111] United States Patent 7,067,213, Boff et al. June 27, 2006. Flow field plate geometries

[112] Wang, C.-T., Huang, R.-Y. Study of proton exchange membrane fuel cell flow slab design. Chung Cheng Ling Hsueh Pao/Journal of Chung Cheng Institute of Technology (2009); 37(2), pp. 79-86 
[113] Wang, C.T., Chang, C.P., Shaw, C.K., Cheng, J.Y. Fuel cell bionic flow slab design. Journal of Fuel Cell Science and Technology (2010); 7(1), pp. 0110091-0110095

[114] Wang, C.-T., Hu, Y.-C., Zheng, P.-L. Novel biometric flow slab design for improvement of PEMFC performance. Applied Energy (2010); 87(4), pp. 1366-1375

[115] Kei K. K. "PEM Fuel Cells Redesign Using Biomimetic and TRIZ Design Methodologies" (2010). Masters Theses.

[116] Arvay, A., French, J., Wang, J., Peng, X., Kannan, A.M. Modeling and simulation of biologically inspired flow field designs for proton exchange membrane fuel cells. Open Electrochem J (2015); 6, pp. 1-9

[117] Heck, Joshua David, "Bio-inspired flow fields for pem fuel cells- decoupling pressure and distribution effects on performance and identifying design opportunities" (2017). Masters Theses. 7647.

[118] Dong-Hui, W., Lin-Zhi, Y., Zhong-Yu, P., Conga-Da, L., Gang, L., Qiao-Hui, L. A novel intersectant flow field of metal bipolar plate for proton exchange membrane fuel cell. International Journal of Energy Research (2017); 41(14), pp. 2184-2193

[119] Atyabi, S.A., Afshari, E. Three-dimensional multiphase model of proton exchange membrane fuel cell with honeycomb flow field at the cathode side. Journal of Cleaner Production (2019); 214, pp. 738-748

[120] Limjeerajarus, N., Santiprasertkul, T. Novel hybrid serpentine-interdigitated flow field with multi-inlets and outlets of gas flow channels for PEFC applications. International Journal of Hydrogen Energy (2019); in press

[121] Behrou, R., Pizzolato, A., Forner-Cuenca, A. Topology optimization as a powerful tool to design advanced PEMFCs flow fields. International Journal of Heat and Mass Transfer (2019); 135, pp. 72-92

[122] FCH JU ID-FAST project: https://hydrogeneurope.eu/project/id-fast ; https://www.fch.europa.eu/project/investigations-degradation-mechanisms-and-definitionprotocols-pem-fuel-cells-accelerated

[123] Georgios Tsotridis, Alberto Pilenga, Giancarlo De Marco, Thomas Malkow; EU harmonised test protocols for PEMFC MEA testing in single cell configuration for automotive applications; JRC Science for Policy report, 2015; EUR 27632 EN; doi 10.2790/54653

[124] Reza Taherian, A review of composite and metallic bipolar plates in proton exchange membrane fuel cell: Materials, fabrication, and material selection, Journal of Power Sources, 265 (2014) 370-390

[125] Hossein Piri, Flow visualization in 3D printed PEM fuel cell bipolar plates, University of British Columbia, Vancouver, Canada (2017).

[126] Shahram Karimi, Norman Fraser, Bronwyn Roberts and Frank R. Foulkes, A Review of Metallic Bipolar Plates for Proton Exchange Membrane Fuel Cells: Materials and Fabrication Methods, Advances in Materials Science and Engineering, 2012, Article ID 828070, 1-22. 
[127] Signe Kjelstrup, Marc-Olivier Coppens, J. G. Pharoah and Peterfeifer, Nature-Inspired Energy- and Material-Efficient Design of a Polymer Electrolyte Membrane Fuel Cell, Energy and Fuels, 24 (2010) 5097-5108.

[128] Kaushik Alayavalli, David L. Bourell, Fabrication of modified graphite bipolar plates by indirect selective laser sintering (SLS) for direct methanol fuel cells, Rapid Prototyping Journal, 16 (2010) 268-274.

[129] J. Shang, L. Wilkerson, S. Hatkevich and G. S. Daehn, Commercialization of Fuel Cell Bipolar Plate Manufacturing by Electromagnetic Forming, ICHSF2010 - 4th International Conference on High Speed Forming, Columbus, Ohio, USA, March 9-10, 2010.

[130] Linfa Peng,Peiyun Yi and Xinmin Lai, Design and manufacturing of stainless steel bipolar plates for proton exchange membrane fuel cells, International Journal of hydrogen energy 39 (2014) 21127-21153.

[131] Majid Elyasi, Hossein Talebi Ghadikolaee and Morteza Hosseinzadeh, Fabrication of metallic bipolar plates in PEM fuel cell using semi-stamp rubber forming process, International Journal of Advanced Manufacturing Technology, 92 (2017) 765-776.

[132] Shinichi Hirano, R\&D for Automotive PEM Fuel Cell System - Bipolar Plates, US DOE Bipolar Plate Workshop, Southfield, MI, USA February 14, 2017.

[133] Simon Farrington, Manufacturing Issues in Bipolar Plate Production, US DOE Bipolar Plate Workshop, Southfield, MI, USA February 14, 2017.

[134] Hossein Piri, Flow visualization in 3D printed PEM fuel cell bipolar plates, MS thesis, University of British Columbia, Vancouver, Canada (2017).

[135] Renata Wlodarczyk, Porous Composite for Bipolar Plate in Low Emission Hydrogen Fuel Cells, Journal of Ecological Engineering, 19 (2018) 225-232.

[136] Yonghua Cai, Zhou Fang, Ben Chen, Tianqi Yang and Zhengkai Tu, Numerical study on a novel 3D cathode flow field and evaluation criteria for the PEM fuel cell design, Energy, 161 (2018) 28-37.

[137] Heidary, H., Kermani, M.J., Advani, S.G., Prasad, A.K. Experimental investigation of in-line and staggered blockages in parallel flowfield channels of PEM fuel cells, International Journal of Hydrogen Energy 41 (2016) 6885-6893

[138] Shen, J., Tu, Z., Chan, S.H. Enhancement of mass transfer in a proton exchange membrane fuel cell with blockage in the flow channel. Applied Thermal Engineering, 149 (2019) 1408-1418

[139] Liu, H.C., Yan, W.M., Soong, C.Y., Chen, F., Chu, H.S. Reactant gas transport and cell performance of proton exchange membrane fuel cells with tapered flow field design, Journal of Power Sources, 158 (2006) 78-87

[140] Wang, X.-D., Huang, Y.-X., Cheng, C.-H., Jang, J.-Y., Lee, D.-J., Yan, W.-M., Su, A. An inverse geometry design problem for optimization of single serpentine flow field of PEM fuel cell, International Journal of Hydrogen Energy, 35 (2010) 4247-4257

[141] Perng, S.-W., Wu, H.-W. Non-isothermal transport phenomenon and cell performance of a cathodic PEM fuel cell with a baffle plate in a tapered channel, Applied Energy, 88 (2011) 5267 
[142] Wang, X.-D., Huang, Y.-X., Cheng, C.-H., Jang, J.-Y., Lee, D.-J., Yan, W.-M., Su, A. Flow field optimization for proton exchange membrane fuel cells with varying channel heights and widths, Electrochimica Acta, 54 (2009) 5522-5530

[143] Wang, C., Zhang, Q., Lu, J., Shen, S., Yan, X., Zhu, F., Cheng, X., Zhang, J. Effect of height/width-tapered flow fields on the cell performance of polymer electrolyte membrane fuel cells, International Journal of Hydrogen Energy, 42 (2017) 23107-23117

[144] Owejan, J.P., Trabold, T.A., Jacobson, D.L., Arif, M., Kandlikar, S.G. Effects of flow field and diffusion layer properties on water accumulation in a PEM fuel cell, International Journal of Hydrogen Energy, 32 (2007) 4489-4502

[145] Al Shakhshir, S., Wang, Y., Alaefour, I., Li, X. The influence of channel wettability on twophase flow and polymer electrolyte membrane fuel cell performance, ECS Transactions, 42 (2012) 109-115

[146] Lu, Z., Rath, C., Zhang, G., Kandlikar, S.G. Water management studies in PEM fuel cells, part IV: Effects of channel surface wettability, geometry and orientation on the two-phase flow in parallel gas channels, International Journal of Hydrogen Energy, 36 (2011) 9864-9875

[147] Yoshida, T., Kojima, K. Toyota MIRAI Fuel Cell Vehicle and Progress Toward a Future Hydrogen Society, Electrochemical Society Interface, 24 (2015) 45-49

[148] Schröder, A., Wippermann, K., Arlt, T., Sanders, T., Baumhöfer, N., Kardjilov, A., Hilger, J., Mergel, W., Lehnert, D., Stolten, J., Banhart, J., Manke, I. Neutron radiography and current distribution measurements for studying cathode flow field properties of direct methanol fuel cells. International Journal of Energy Research, 38 (2014) 926-943.

[149] Kang, H.C., Jum, K.M., Sohn, Y.J. Performance of unit PEM fuel cells with a leaf-veinsimulating flow field-patterned bipolar plate, International Journal of Hydrogen Energy, 44 (2019) 24036-24042

[150] Liu, S., Chen, T., Xie, Y., Zhang, J., Wu, C. Numerical simulation and experimental study on the effect of symmetric and asymmetric bionic flow channels on PEMFC performance under gravity, International Journal of Hydrogen Energy, 2019, In Press 